\title{
Predator size - prey size relationships of marine fish predators: interspecific variation and effects of ontogeny and body size on trophic-niche breadth
}

\author{
Frederick S. Scharf ${ }^{1, *}$, Francis Juanes ${ }^{2}$, Rodney A. Rountree ${ }^{3, * *}$ \\ ${ }^{1}$ Department of Natural Resources Conservation, University of Massachusetts, Amherst, Massachusetts 01003, USA \\ ${ }^{2}$ Department of Natural Resources Conservation and Graduate Program in Organismic and Evolutionary Biology, \\ University of Massachusetts, Amherst, Massachusetts 01003, USA \\ ${ }^{3}$ NOAA/NMFS/NEFSC, Woods Hole Marine Laboratory, 166 Water St., Woods Hole, Massachusetts 02543, USA
}

\begin{abstract}
We utilized a long-term data base collected over a broad geographic range to examine predator size - prey size relationships for 18 species of marine fish predators from continental shelf waters off the northeast US coast. Regression analysis was used to illustrate interspecific variation in ontogenetic patterns of prey size use, gape allometries, and ratio-based trophic niche breadths. Sizebased feeding strategies were assessed through comparison of frequency distributions of relative prey sizes eaten and were related to general predator feeding tactics and gape morphology. The results demonstrated that the range of prey sizes eaten expanded with increasing predator body size for each of the marine predators examined, leading to asymmetric predator size - prey size distributions. Absolute maximum prey size and slopes of maximum prey size versus predator size varied widely among predator taxa. Distinct size-based feeding strategies were evident, as diets of some predators were dominated by prey that were 10 to $20 \%$ of predator size, whereas other predators frequently consumed prey $>50 \%$ of predator size. Gape sizes and allometric relationships with body size were also diverse among predators and often were closely associated with maximum prey sizes. Ratio-based trophic-niche breadths generally did not expand with predator ontogeny and tended to narrow for the largest predators, which may be common for animal taxa.
\end{abstract}

KEY WORDS: Predator-prey $\cdot$ Body size $\cdot$ Piscivorous fish $\cdot$ Trophic niche $\cdot$ Gape size

\section{INTRODUCTION}

A common goal of food habits research is to predict the composition of the diet of an animal given its size, its morphological and behavioral characteristics, and the available food resources. Predators may feed indiscriminately on the most abundant prey in their sur-

Present addresses:

*NOAA/NMFS/NEFSC, James J. Howard Marine Laboratory, 74 Magruder Rd., Highlands, New Jersey 07732, USA. E-mail: fred.scharf@noaa.gov

${ }^{* *}$ Department of Natural Resources Conservation, University of Massachusetts, Amherst, Massachusetts 01003, USA roundings or they may feed selectively on specific prey from those available, with the potential for several factors to contribute to the selection patterns observed (Eggers 1977, Greene 1986, Sih \& Moore 1990). To this end, the focus of a large body of empirical work has been the development of quantitative relationships between patterns of prey use and attributes of both predator and prey (Folkvord \& Hunter 1986, Hart \& Hamrin 1990, Litvak \& Leggett 1992, Juanes 1994, Christensen 1996).

In aquatic communities, body size of both prey and predator is 1 attribute that has been linked directly to foraging success. Predators become more successful with size due to a variety of factors including increased 
sustained and burst swimming speeds and better visual acuity (Keast \& Webb 1966, Webb 1976, Beamish 1978, Blaxter 1986). The escape response of prey is also strongly related to body size, as reaction distances increase and swimming performance is enhanced with size (Folkvord \& Hunter 1986, Blaxter \& Fuiman 1990). Further, the morphology of predators and prey change with ontogeny as predator gape size increases and morphological defenses of prey (e.g. spines) become more robust. The relation between prey size and predator size has therefore been recognized as being of paramount importance in determining the outcome of interactions among species.

For most fishes, the sizes of prey consumed generally increase with increasing predator size (Keast \& Webb 1966, Popova 1967, 1978, Nielsen 1980, Persson 1990, Juanes 1994). In addition, the range of prey sizes eaten typically increases in larger predators, with maximum prey size increasing while minimum prey size often changes only slightly over a broad range of predator sizes. Such asymmetric patterns in predator size - prey size distributions have generated hypotheses about competitive interactions among predators of different size; in terms of prey size, the diet of smaller predators is a subset of the diet of larger predators (Brooks \& Dodson 1965, Hall et al. 1970, Wilson 1975). Thus, larger predators may have a competitive advantage by feeding on small prey sizes while also being able to feed on large prey that are unavailable to smaller predators.

The prevalence of asymmetric predator size-prey size distributions in aquatic ecosystems provokes inquiry as to the nature of their existence. Why should large predators continue to include small prey in their diet? Traditional foraging theory predicts that animals should maximize their net rate of energy return when selecting prey (Schoener 1971, Charnov 1976, Stephens \& Krebs 1986), with models for particulate feeders often predicting that the largest prey available should be eaten to maximize feeding efficiency (Ivlev 1961, Werner \& Hall 1974, Harper \& Blake 1988). However, several examples indicate that smaller prey are selected over larger prey when predators are given a choice (Gillen et al. 1981, Hoyle \& Keast 1987, Hart \& Hamrin 1990, Juanes 1994), suggesting that currencies used in foraging models to estimate the relative costs and benefits of different sized prey may be incomplete.

In attempts to characterize the ecological niche of an individual, measures of prey size have been used to represent the trophic niche of animal taxa (Schoener \& Gorman 1968, Roughgarden 1972, 1974). Several recent studies have examined trophic-niche breadth in fishes on a ratio scale by examining changes in the standard deviation of log-transformed prey-size data as predator size increases (Pearre 1986, Munk 1992,
1997, Pepin \& Penney 1997). In order to identify general ontogenetic trends in patterns of prey size use by fish predators, Pearre (1986) examined several predator taxa and size ranges and concluded that the range of relative prey sizes did not change significantly with predator size for most species. In contrast, Pepin \& Penney (1997) found significant increases in ratiobased trophic-niche breadth in 6 larval fish species and positive trends in 3 others. When examined collectively, however, the results of past studies on the ontogeny of trophic-niche breadth in fishes, whether based on ontogenetic changes in relative or absolute prey size, reveal several patterns that may be generalizable across taxa. Thus, a clear need remains for the further study of patterns of prey size use by predators that are comprehensive, employing similar protocols and incorporating several species and ontogenetic stages.

Here, we use an extensive long-term data set to examine size-based feeding habits of a diverse group of marine fish predators in coastal waters off the northeast US continental shelf. For the purposes of examining predators that consume large prey relative to their own size, we focus on predators that demonstrate piscivorous feeding habits during 1 or more stages of their life history. We examine predator size - prey size relationships in order to determine ontogenetic changes in minimum, mean, and maximum prey sizes consumed. Variation in predator size-prey size relationships among different predator species are related to species-specific attributes of predators, including predator gape size, morphology, and feeding behavior. Frequency distributions of relative prey sizes consumed, based on prey/predator size ratios, are compared across taxa to identify general size-based feeding patterns. We also examine ontogenetic changes in trophic-niche breadth of predators based on relative prey size, rather than absolute prey size, and relate interspecific variation in the breadth of relative prey sizes to the rate of increase in maximum absolute prey size and average predator size.

\section{MATERIALS AND METHODS}

Data source. The data used for this study were collected as part of fisheries-independent resource monitoring conducted in marine waters over the continental shelf of the northeast US since 1963 by the Northeast Fisheries Science Center (NMFS, NOAA). Survey details can be found in Azarovitz (1981). Briefly, sampling is conducted for approximately $8 \mathrm{wk}$ during fall (September and October) and spring (March and April) each year. In addition to fall and spring surveys, winter and summer sampling are completed during 


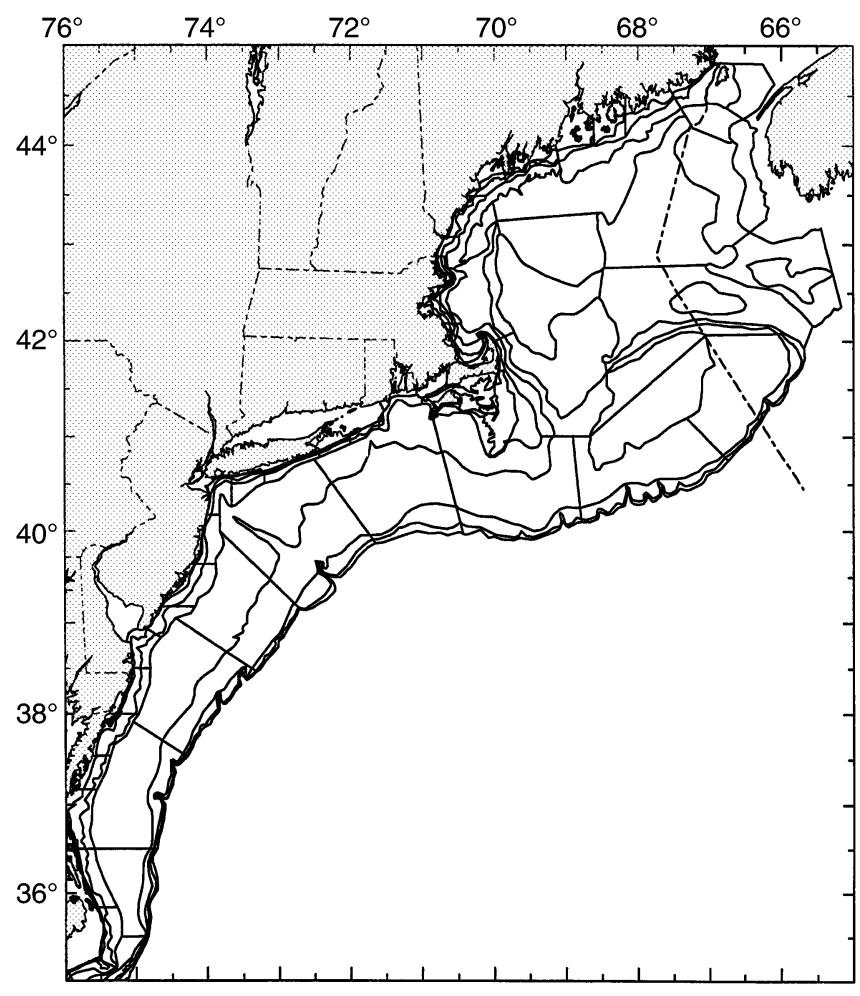

Fig. 1. Map of northeast US coast from Cape Hatteras, North Carolina (S) to Nova Scotia, Canada (N). Continuous lines = sampling strata (depth zones) for National Marine Fisheries Service bottom-trawl surveys conducted in continental shelf waters; outermost continuous line $=$ depths $>185 \mathrm{~m}$; single dashed line on right: position of USA/Canadian border (Hague line)

some years. Fish are captured in trawls (Yankee-type with $10 \mathrm{~m}$ approximate wingspread; $12.7 \mathrm{~cm}$ mesh wings; $1.27 \mathrm{~cm}$ mesh cod-end liner) equipped with rollers to make rough bottom tows possible. Trawls are fished on the bottom in waters between 3 and 200 nautical miles offshore from Cape Lookout, North Carolina northward to waters off Nova Scotia (Fig. 1).

The sampling design is stratified random, with strata defined by latitude, depth, and historical fishing information. Approximately 350 to 400 stations are completed during each season, with the number of stations allotted to each stratum based on stratum size. Each station within each stratum is randomly selected and consists of a 30 min tow at a speed of 3.5 knots. The catch is sorted by species and either entire samples or representative subsamples of fishes are measured to the nearest centimeter. Subsamples of predatory fishes are randomly sampled for analysis of stomach contents. Criteria for subsampling has changed during the survey period, but effort is made to insure that representative size distributions of predators are sampled at each station or within each stratum. Samples of stomach contents are either processed at sea or preserved in a $10 \%$ formalin/seawater solution and processed in the laboratory. Prey items are enumerated, identified to the lowest possible taxon, weighed (or percent stomach volume estimated at sea), and measured to the nearest millimeter total length.

This study utilizes data collected during 1973 to 1990 for which both predator size and prey size information was obtained. Although collection of prey size data during this period was aimed at obtaining measurements for fishes and commercially important invertebrates such as squid, shrimp, and crabs, other invertebrate prey were measured periodically throughout the survey period. For this study, prey include all fishes and invertebrate species that were measured.

Predators and prey. A diverse group of 18 marine fish predators that vary in size, morphology, and behavior was selected for this study (Table 1). Each of the predators in the group is piscivorous throughout some or most of its life cycle, but each predator also feeds on varying amounts of invertebrate prey in addition to fish prey. The group includes fishes that occupy benthic, pelagic, and demersal habitats, as well as fishes common to both inshore and offshore waters of this region. Represented are 9 families and 14 genera that include several flatfishes, groundfishes, sculpins, anglerfishes, fast-swimming pelagics, and a variety of elasmobranchs. Morphological and behavioral descriptions of individual predator species can be found in Bigelow \& Schroeder (1953). Both juvenile and adult fishes are represented as predator sizes range from 60 to $1500 \mathrm{~mm}$ in length, with average lengths between 250 and $930 \mathrm{~mm}$. The prey field encompasses a wide variety of fishes and invertebrate species that is too exhaustive to list and describe here. Some of the most abundant prey by weight and number consumed by the predators listed in Table 1 include herring (family Clupeidae); sand lance (Ammodytes spp.); cod (family Gadidae); mackerel (family Scombridae); flatfish (family Pleuronectidae); pandalid shrimp (family Pandalidae); and cancer crabs (family Cancridae). Complete descriptions of the taxonomic composition of the diets of predators listed in Table 1 are presented for an earlier time period in Edwards \& Bowman (1979), Langton \& Bowman (1980, 1981), and Sedberry (1983).

Data analysis. Interspecific variability and changes in prey size use patterns with ontogeny were examined using regression analysis. Prey size - predator size scatter diagrams were plotted for each predator species and least-squares regressions were generated to estimate the relationship between mean prey size and predator size. To estimate changes in minimum and maximum prey size with increasing predator size, the edges of each scatter diagram were analyzed using quantile regression procedures (Scharf et al. 1998b, Cade et al. 1999). Regression quantiles between 0 and 
Table 1. Marine fish predators from US northeast continental shelf waters examined in this study, listed in ascending order of mean size. Mean size and range are total length in $\mathrm{mm} ; \mathrm{n}=$ number of individual prey fishes with length information recovered from the stomachs of each predator species

\begin{tabular}{|c|c|c|c|}
\hline Predator species & Mean size & Range & $\mathrm{n}$ \\
\hline Spotted hake Urophycis regia & 250 & $70-400$ & 286 \\
\hline Fourspot flounder Paralichthys oblongus & 280 & $160-390$ & 450 \\
\hline Windowpane Scopthalmus aquosus & 280 & $170-390$ & 307 \\
\hline Longhorn sculpin Myoxocephalus octodecimspinosus & 280 & $120-370$ & 299 \\
\hline Sea raven Hemitripterus americanus & 310 & $100-620$ & 403 \\
\hline Silver hake Merluccius bilinearis & 320 & $60-620$ & 1391 \\
\hline Red hake Urophysis chuss & 350 & $110-630$ & 552 \\
\hline Weakfish Cynoscion regalis & 350 & $110-790$ & 523 \\
\hline Summer flounder Paralichthys dentatus & 360 & $190-820$ & 373 \\
\hline Little skate Raja erinacea & 430 & $110-540$ & 838 \\
\hline Bluefish Pomatomus saltatrix & 470 & $110-880$ & 991 \\
\hline White hake Urophycis tenuis & 520 & $150-1280$ & 791 \\
\hline Goosefish Lophius americanus & 600 & $130-1120$ & 409 \\
\hline Atlantic cod Gadus morhua & 670 & $210-1500$ & 2346 \\
\hline Pollock Pollachius virens & 700 & $270-1060$ & 271 \\
\hline Winter skate Raja ocellata & 760 & $290-1090$ & 1290 \\
\hline Spiny dogfish Squalus acanthius & 820 & $230-1100$ & 3253 \\
\hline Smooth dogfish Mustelus canis & 930 & $460-1250$ & 1313 \\
\hline
\end{tabular}

100 can be estimated through minimization of the sums of the absolute values of residuals. The estimated quantiles are generally robust to outlying values along the $y$-axis and the procedure is ideally suited to the examination of data with heteroscedastic error distributions (StataCorp. 1999, Scharf et al. 1998b). Quantiles ranged between the 90th and 99th for upper bounds and the 1st and 10th for lower bounds, and were based on sample sizes for individual predators (Scharf et al. 1998b, Cade et al. 1999). Correlation analyses were performed among minimum, mean, and maximum prey size slope estimates to determine whether increases in mean prey size were primarily a result of changes in minimum or maximum prey size. Patterns of relative prey size use among predators were examined by generating relative frequency histograms of prey size/predator size ratios consumed by each predator.

As part of fisheries monitoring surveys conducted in 1995 and 1996, predator species were collected to obtain morphological measurements of gape height and gape width. Sufficient numbers and size ranges were collected for 8 of the predator species listed in Table 1. Gape height was defined as the maximum linear distance between the upper and lower jaws with the mouth stretched open. Gape width was defined as the linear distance between the left and right corners of the open mouth. Least-squares regressions were performed to determine gape size versus body size relationships for the 8 predators. Lengths of prey eaten by these predators were converted to dorsoventral body depths using depth/length relationships specific to each prey taxon (Scharf et al. 1998c). For each scatter diagram of prey body depth versus predator length, maximum prey body depths consumed were estimated using regression quantiles. Slopes of prey body depth versus predator size regressions were compared to gape estimates using post-hoc tests (Sokal \& Rohlf 1995, p. 500).

Trophic-niche breadth was examined on a ratio scale by determining changes in the range of relative prey sizes with increasing predator size. Prey size data were converted to a ratio scale by dividing each prey size by its corresponding predator size and then plotting these prey/predator size ratios versus predator size. Regression quantiles (90th and 10th) were generated to estimate the extremes of the ratio scale data for each predator. Using regression quantiles to estimate the rate of change in the extremes of the data eliminated the need to subjectively partition predator size data into separate size classes for the purposes of estimating means and standard deviations within each size class, as has been done in previous ratio-based trophic-niche breadth studies (Pearre 1986, Munk 1992, 1997, Pepin \& Penney 1997). Slope comparisons were made between upper and lower bounds, with significant differences indicating an increase or decrease in ratio-based trophic-niche breadth with increasing predator size. Convergent slopes indicated a decrease; divergent slopes indicated an increase. The difference between predicted values of upper and lower bound regressions at any given predator size represented the trophic-niche breadth. For each predator species, predicted niche breadths were re- 
gressed against predator size and the resultant slopes were compared to the slopes for maximum and minimum prey size generated from the original scatter diagrams. This allowed us to determine whether or not predators that increased their maximum or minimum prey size rapidly as they grew experienced an increase or decrease in trophic-niche breadth relative to those predators that increased their maximum or minimum prey size more slowly. Average trophicniche breadth was also compared to average predator size to evaluate whether a general size-based trend was apparent.

\section{RESULTS}

The range of absolute prey sizes eaten expanded with increasing body size for all predators examined. As body size increased, all predators showed a significant increase in maximum prey size consumed, while 12 of 18 predators increased minimum prey sizes eaten (Fig. 2, Table 2). Upper-bound slopes spanned an order of magnitude, ranging from 0.077 to 0.894 (Fig. 3, Table 2). Although ranging from 0.0 to 0.170 , lowerbound slopes were less variable among predators, as all but 4 slopes were $<0.030$ (Fig. 3, Table 2). The continued inclusion of small prey in the diet across a range of predator body sizes resulted in asymmetric predator size - prey size distributions for each predator. Mean prey size - predator size slopes were positively related to upper bound slopes $(\mathrm{r}=0.802 ; \mathrm{p}<0.001)$ and were not related to lower bound slopes $(r=0.308 ; p=0.213)$, demonstrating that ontogenetic changes in mean prey sizes eaten were driven primarily by changes in maximum prey sizes consumed. Upper- and lower-bound slope estimates were not correlated $(\mathrm{r}=-0.026 ; \mathrm{p}=$ 0.918 ), indicating that predators with rapid ontogenetic increases in maximum prey size did not necessarily increase minimum prey size rapidly.

A considerable amount of variation was present among predators in the relative frequency distributions of prey size/predator size ratios (Fig. 4). Several predators consumed mainly prey that were small fractions of their body size. For example, nearly $75 \%$ of the diet of the predators illustrated in Fig. 4a consisted of prey $<20 \%$ of their own body size. Two of these predators, smooth dogfish and little skate, had diets that were dominated by invertebrates, resulting in $90 \%$ of their diets being made up of small prey $(<20 \%$ predator size). On the other hand, the predators depicted in Fig. 4b incorporated a considerable number of intermediate-sized prey in their diets while they also continued to feed on several small prey. For this group of predators, 30 to $40 \%$ of their diets consisted of prey $>20 \%$ of their own body size. The predators illustrated in Fig. 4c consumed an abundance of relatively large prey, as 45 to $75 \%$ of the diet was made up of prey $>20 \%$ of their own body size, including several prey greater than $50 \%$ of their body size. For example, nearly $30 \%$ of the diets of silver hake and white hake

Table 2. Regression equations relating maximum, mean, and minimum prey size to predator size for marine fish predators in Table 1. Estimates for maximum and minimum prey sizes were generated using quantile regression techniques; estimates for mean prey sizes are least-squares estimates. PY = maximum, mean, or minimum prey total length in millimeters; $\mathrm{PD}=$ predator total length in $\mathrm{mm}$; quantiles listed are those used to estimate upper and lower bounds of each prey size/predator size scatter plot. NS = regression coefficient not significant; $p>0.05$

\begin{tabular}{|c|c|c|c|c|c|}
\hline Predator species & Maximum & Mean & Minimum & $\mathrm{n}$ & Quantiles \\
\hline Spotted hake & $\mathrm{PY}=0.495 \mathrm{PD}+5.579$ & $\mathrm{PY}=0.227 \mathrm{PD}-1.544$ & $\mathrm{PY}=0.020 \mathrm{PD}+4.800^{\mathrm{NS}}$ & 286 & 90 th $/ 10$ th \\
\hline Fourspot flounder & $\mathrm{PY}=0.367 \mathrm{PD}-15.667$ & $\mathrm{PY}=0.218 \mathrm{PD}-24.641$ & $\mathrm{PY}=0.011 \mathrm{PD}+2.111^{\mathrm{NS}}$ & 450 & 95 th/5th \\
\hline Windowpane & $\mathrm{PY}=0.419 \mathrm{PD}-1.563$ & $\mathrm{PY}=0.395 \mathrm{PD}-52.123$ & $\mathrm{PY}=0.170 \mathrm{PD}-31.000$ & 307 & 95 th/5th \\
\hline Longhorn sculpin & $\mathrm{PY}=0.330 \mathrm{PD}+15.900$ & $\mathrm{PY}=0.006 \mathrm{PD}+37.154^{\mathrm{NS}}$ & $\mathrm{PY}=0.021 \mathrm{PD}+0.929^{\mathrm{NS}}$ & 299 & 95 th/5th \\
\hline Sea raven & $\mathrm{PY}=0.894 \mathrm{PD}+22.000$ & $\mathrm{PY}=0.512 \mathrm{PD}-13.819$ & $\mathrm{PY}=0.005 \mathrm{PD}+18.524^{\mathrm{NS}}$ & 403 & 95 th/5th \\
\hline Silver hake & $\mathrm{PY}=0.580 \mathrm{PD}+27.400$ & $\mathrm{PY}=0.416 \mathrm{PD}-37.106$ & $\mathrm{PY}=0.027 \mathrm{PD}-0.577$ & 1391 & 99th/1st \\
\hline Red hake & $\mathrm{PY}=0.633 \mathrm{PD}-58.000$ & $\mathrm{PY}=0.270 \mathrm{PD}-32.517$ & $\mathrm{PY}=0.011 \mathrm{PD}+4.643$ & 552 & 95 th/5th \\
\hline Weakfish & $P Y=0.156 P D+60.976$ & $\mathrm{PY}=0.060 \mathrm{PD}+36.320$ & $\mathrm{PY}=0.053 \mathrm{PD}+1.842$ & 523 & 95 th $/ 5$ th \\
\hline Summer flounder & $\mathrm{PY}=0.333 \mathrm{PD}-3.333$ & $\mathrm{PY}=0.209 \mathrm{PD}-6.395$ & $P Y=0.100 P D-16.000$ & 373 & 90th/10th \\
\hline Little skate & $P Y=0.320 P D+0.800$ & $P Y=0.075 P D+7.981$ & $\mathrm{PY}=0.022 \mathrm{PD}-3.000$ & 838 & 95 th $/ 5$ th \\
\hline Bluefish & $P Y=0.462 P D+30.769$ & $P Y=0.112 P D+34.894$ & $\mathrm{PY}=0.016 \mathrm{PD}+5.920$ & 991 & 99th/1st \\
\hline White hake & $\mathrm{PY}=0.471 \mathrm{PD}+48.824$ & $P Y=0.268 P D+14.989$ & $\mathrm{PY}=0.089 \mathrm{PD}-20.395$ & 791 & 95 th $/ 5$ th \\
\hline Goosefish & $P Y=0.323 P D+185.077$ & $P Y=0.129 P D+120.320$ & $\mathrm{PY}=0.002 \mathrm{PD}+33.293^{\mathrm{NS}}$ & 409 & 95 th/5th \\
\hline Atlantic cod & $P Y=0.435 P D+32.609$ & $P Y=0.199 P D-21.107$ & $\mathrm{PY}=0.022 \mathrm{PD}-6.741$ & 2346 & $99 \mathrm{th} / 1 \mathrm{st}$ \\
\hline Pollock & $\mathrm{PY}=0.259 \mathrm{PD}+51.852$ & $\mathrm{PY}=0.135 \mathrm{PD}+30.917$ & $\mathrm{PY}=0.000 \mathrm{PD}+30.000^{\mathrm{NS}}$ & 271 & $95 \mathrm{th} / 5 \mathrm{th}$ \\
\hline Winter skate & $P Y=0.133 P D+136.667$ & $\mathrm{PY}=0.130 \mathrm{PD}+8.561$ & $P Y=0.015 P D-1.692$ & 1290 & 99th/1st \\
\hline Spiny dogfish & $\mathrm{PY}=0.324 \mathrm{PD}+70.588$ & $\mathrm{PY}=0.112 \mathrm{PD}+23.072$ & $\mathrm{PY}=0.014 \mathrm{PD}+0.864$ & 3253 & 99th/1st \\
\hline Smooth dogfish & $P Y=0.077 P D+73.077$ & $\mathrm{PY}=0.049 \mathrm{PD}+12.758$ & $\mathrm{PY}=0.015 \mathrm{PD}+1.846$ & 1313 & 95 th/5th \\
\hline
\end{tabular}


a)
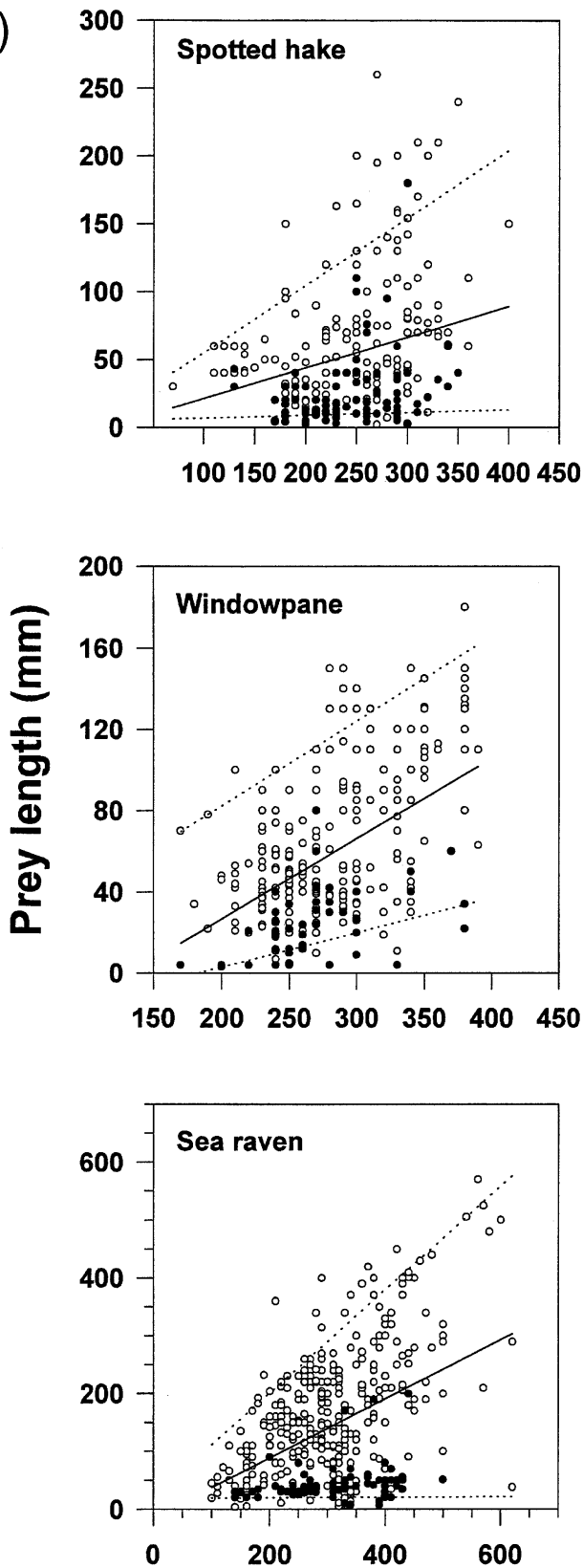
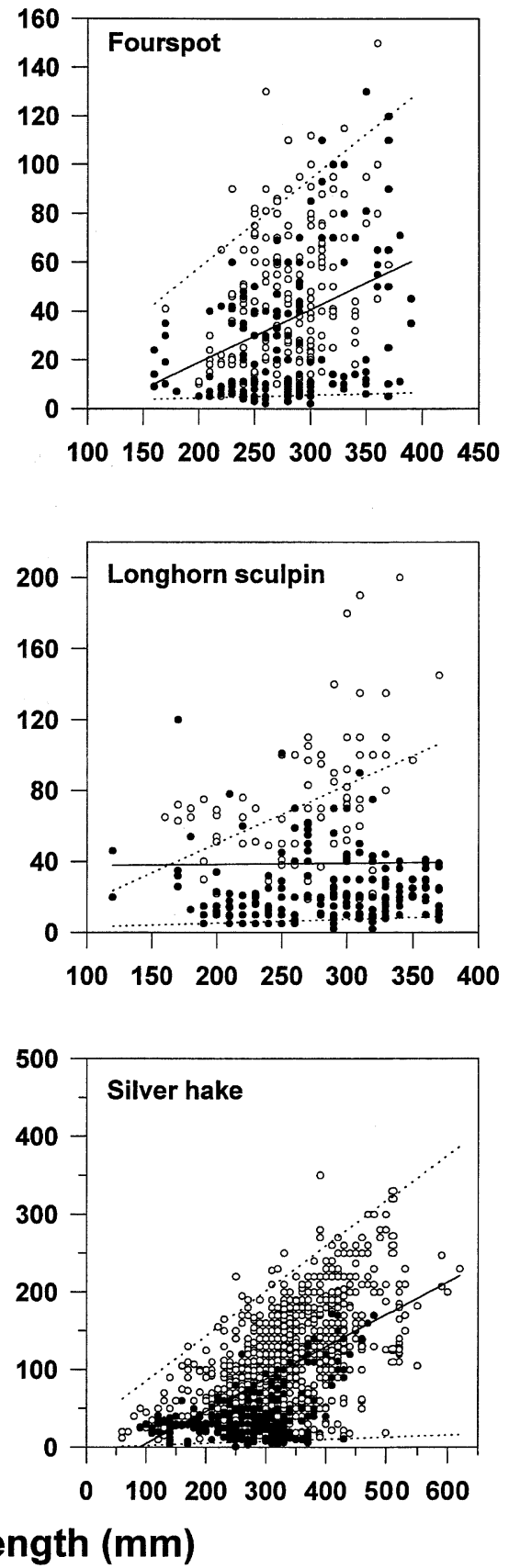

Fig. 2. Predator size - prey size scatter diagrams for predatory fishes from marine waters off US northeast continental shelf. Each symbol represents a single prey consumed by a predator. (०) Fish prey; ( $\bullet$ ) invertebrate prey; regression lines $=$ ontogenetic changes in prey sizes consumed with increasing predator size for all prey combined; dashed lines = minimum and maximum prey sizes; continuous lines = mean prey sizes. Regression equations are presented in Table 2 . Predators are shown in ascending order of mean size from upper left to lower right and from (a) to (c)

were made up of prey $>40 \%$ of their size, whereas over 30 and $45 \%$ of the diets of goosefish and sea raven, respectively, consisted of prey $>50 \%$ of predator size. The diets of several members of this group (bluefish, white hake, sea raven, goosefish) were more concentrated on fish, rather than invertebrates, when compared to other predators (Fig. 2). For the 8 predators with gape size data, ratios of gape size relative to predator size ranged from 0.04 for spiny dogfish to 0.24 for goosefish and were strongly correlated with the proportion of prey in the diet that was $>40 \%$ of predator size $(r=0.887 ; p=0.003)$. 

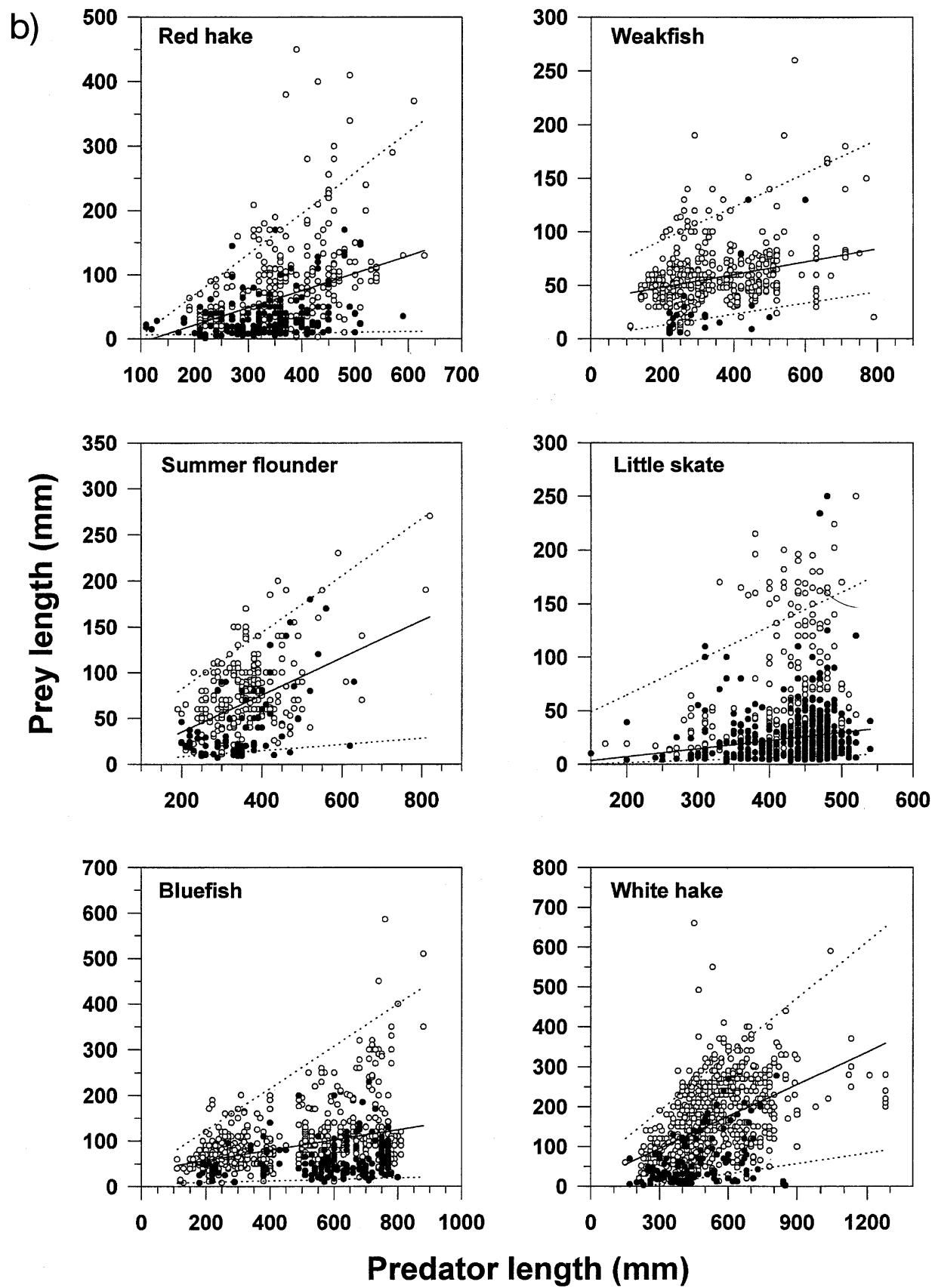

Fig. 2 (continued)

Gape sizes of predators increased linearly with increasing body size, however, regression slopes were varied (Fig. 5, Table 3). Spiny dogfish and red hake showed only gradual increases in gape size with increasing body size, whereas gape sizes of sea raven and goosefish increased nearly 4 times faster through ontogeny. For 5 of 8 predators examined, gape size appeared to be a good indicator of maximum prey size consumed, as gape size regressions had statistically similar slopes to upper-bound prey size regressions
(Table 3). Elevations ( $y$-intercepts) of gape size regressions were higher than those of upper-bound prey size regressions; however, several large prey were located above the upper-bound prey size regression for each predator. For 3 predators (goosefish, winter skate, and bluefish), upper-bound prey size regressions were much lower than gape size regressions, and slopes were significantly different. Although gape height and width measurements generally scaled similarly with increasing body size, gape height more closely corre- 
c)
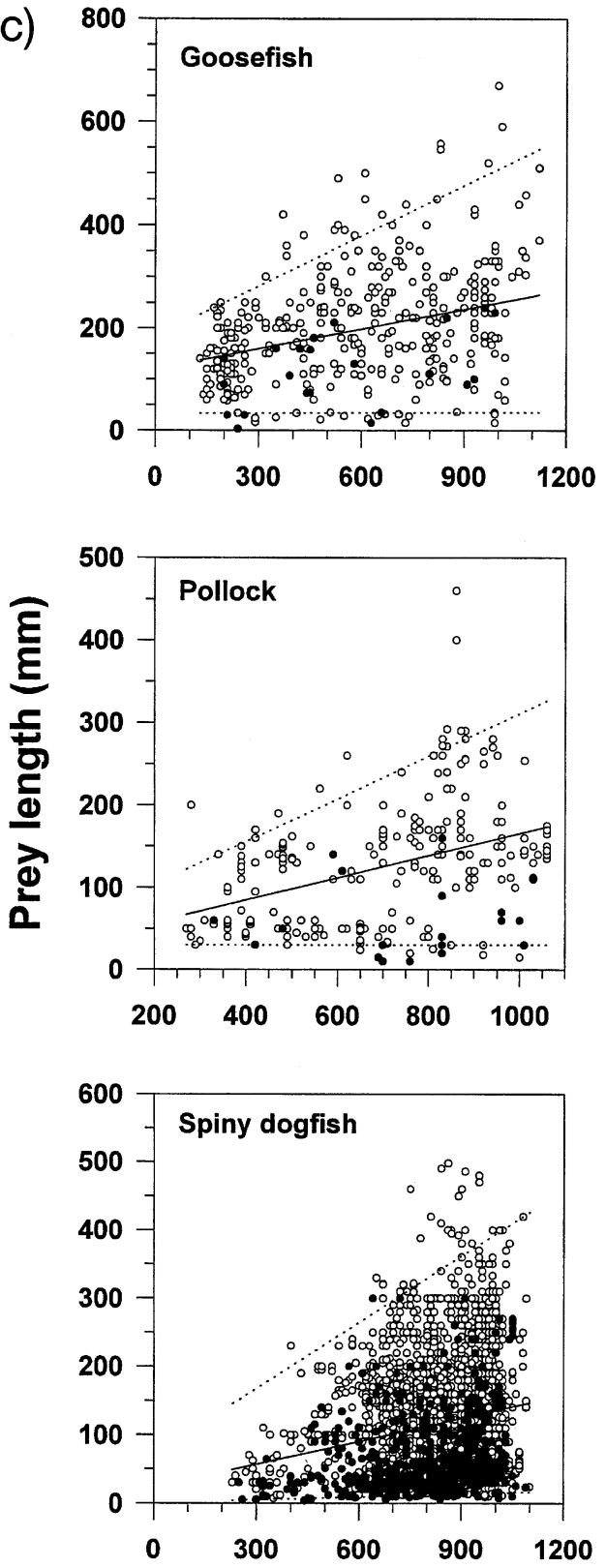
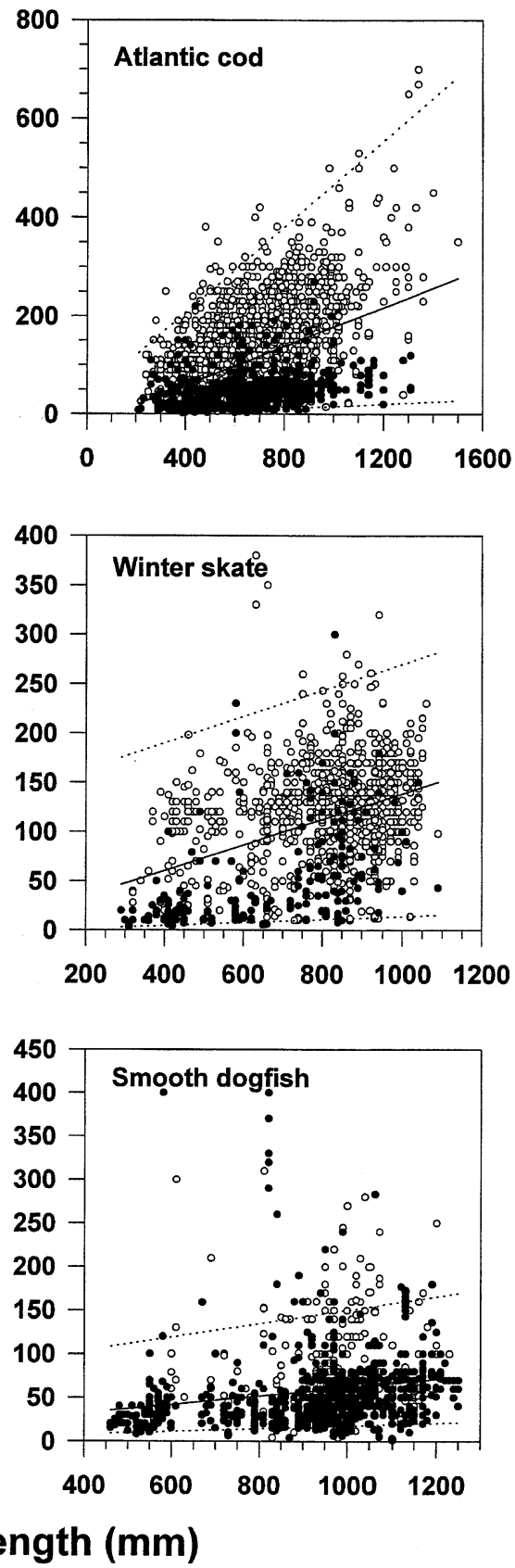

Fig. 2 (continued)

sponded with maximum prey size eaten for 4 of 5 predators based on the slopes and significance levels of comparison tests presented in Table 3 .

Only 7 of the 18 predators examined demonstrated a significant change in ratio-based trophic-niche breadth with increasing body size (Table 4). The general trend was for smaller average-sized predators to show no significant change, while the largest predators tended to show a decrease in ratio-based trophic-niche breadth with increasing body size (Fig. 6). For exam- ple, 5 of the 7 largest average-sized predators had decreasing ratio-based trophic-niche breadths, whereas the 6 smallest average-sized predators demonstrated no ontogenetic change in ratio-based trophicniche breadth (Table 4). Although variable, average ratio-based trophic-niche breadth demonstrated a declining trend with increasing average predator size across the range of predators examined (Fig. 7). Slopes generated from regressions of the difference between upper and lower bounds of relative prey size data ver- 


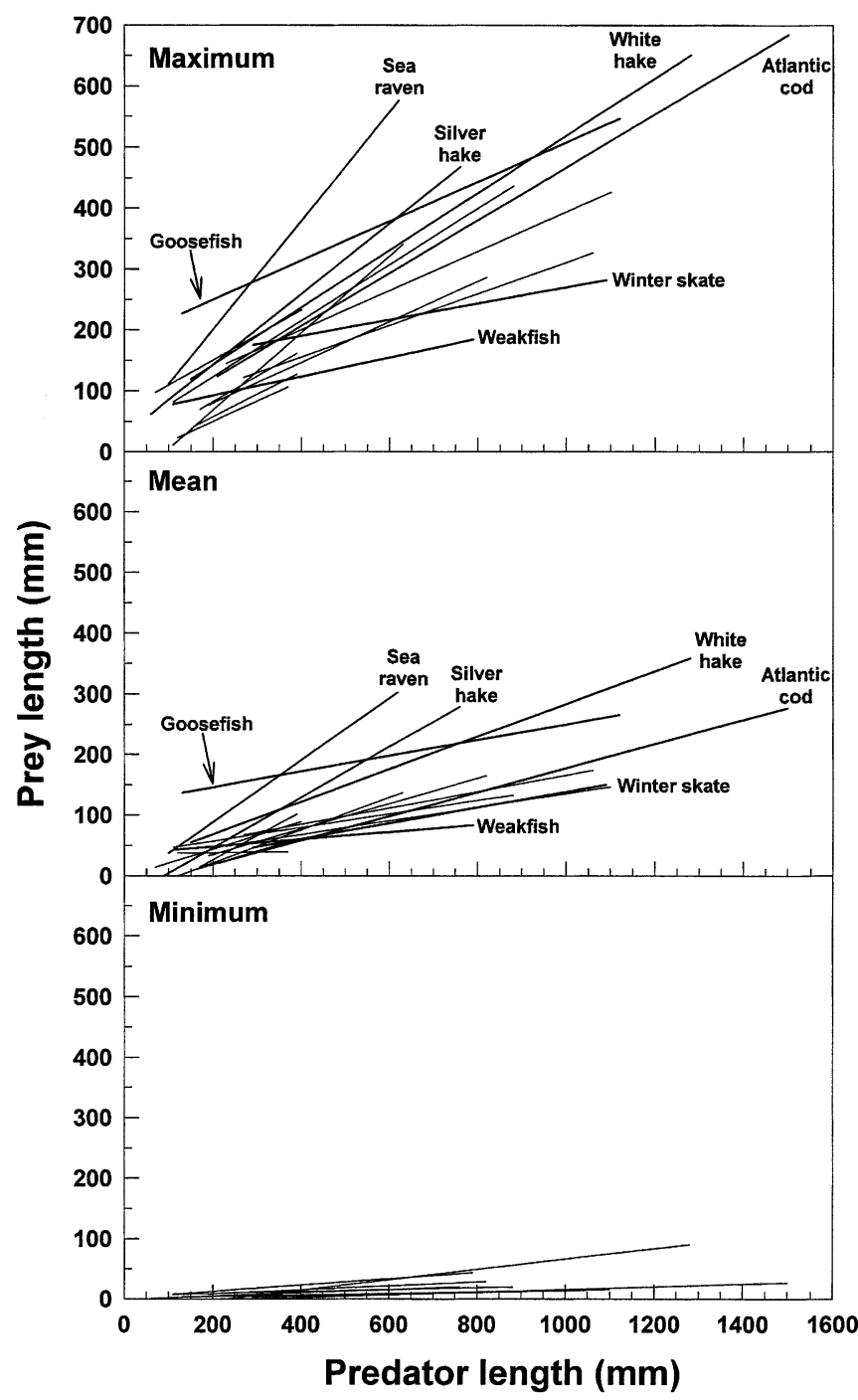

Fig. 3. Regressions illustrating ontogenetic changes in maximum, mean, and minimum prey sizes consumed with increasing predator size for all marine fish predators examined in this study. Regression equations are presented in Table 2. Each graph is intended to illustrate among-predator variation in prey sizes eaten. As reference points, positions of several, but not all, predators are indicated

sus predator size were positively related to the slopes of maximum prey size versus predator size regressions presented in Table 2 and were not significantly related to the slopes of minimum prey size versus predator size regressions (Fig. 8).

\section{DISCUSSION}

Predator size - prey size distributions were asymmetric, with the range of prey sizes eaten expanding with increasing predator body size for each of the marine predators examined. Despite the consistency in the general shapes of the distributions, maximum prey size and the rate of change in maximum prey size with ontogeny varied widely among predator taxa. Differential size-based feeding strategies were evident, as predator diets were concentrated on varying ranges of relative prey sizes from prey that were 10 to $20 \%$ of predator size to prey $>50 \%$ of predator size. Similar to the variability present in prey sizes consumed, gape sizes and allometric relationships with body size were diverse among predators. Lastly, ratio-based trophicniche breadths generally did not expand with predator ontogeny and tended to narrow for the largest predators.

\section{Existence of asymmetric predator size - prey size patterns}

The general patterns of prey size use by predators in this study correspond well with previous studies of predation by fishes (Popova 1967, 1978, Shirota 1970, Hunter 1981, Persson 1990, Juanes \& Conover 1995, Mittelbach \& Persson 1998). Collectively, these findings support the notion of a widespread existence of asymmetric predator size-prey size distributions in aquatic ecosystems. The continued inclusion of small prey in the diets of larger predators contrasts with predictions of optimal foraging models for particulate feeders, which indicate that the largest prey available should be consumed preferentially to maximize net energetic return (Ivlev 1961, Werner \& Hall 1974, Gillen et al. 1981, Harper \& Blake 1988). However, many previous foraging models have used only the time required to handle individual prey to represent foraging costs (Werner 1974, Gillen et al. 1981, Stein et al. 1984), ignoring potential prey behavior that can affect encounter rates and capture efficiencies (Sih \& Moore 1990). For planktivorous fishes, models that estimate foraging costs based only on prey handling time have proven successful in predicting patterns of prey selection (Werner \& Hall 1974, Kislalioglu \& Gibson 1976, Mittelbach 1981, Wanzenböck 1995). Piscivores, however, generally spend less time feeding compared to planktivores (Breck 1993). Therefore, handling time may be of little importance relative to size-dependent capture success and differential encounter probabilities in determining patterns of prey selection by piscivorous fishes (Breck 1993, Juanes \& Conover 1994).

Prey vulnerability is strongly affected by body size, and can be expressed as the product of encounter probability and susceptibility to capture (Greene 1983, 1986, Juanes 1994). Predator capture success is known to decrease monotonically with increasing prey size for 


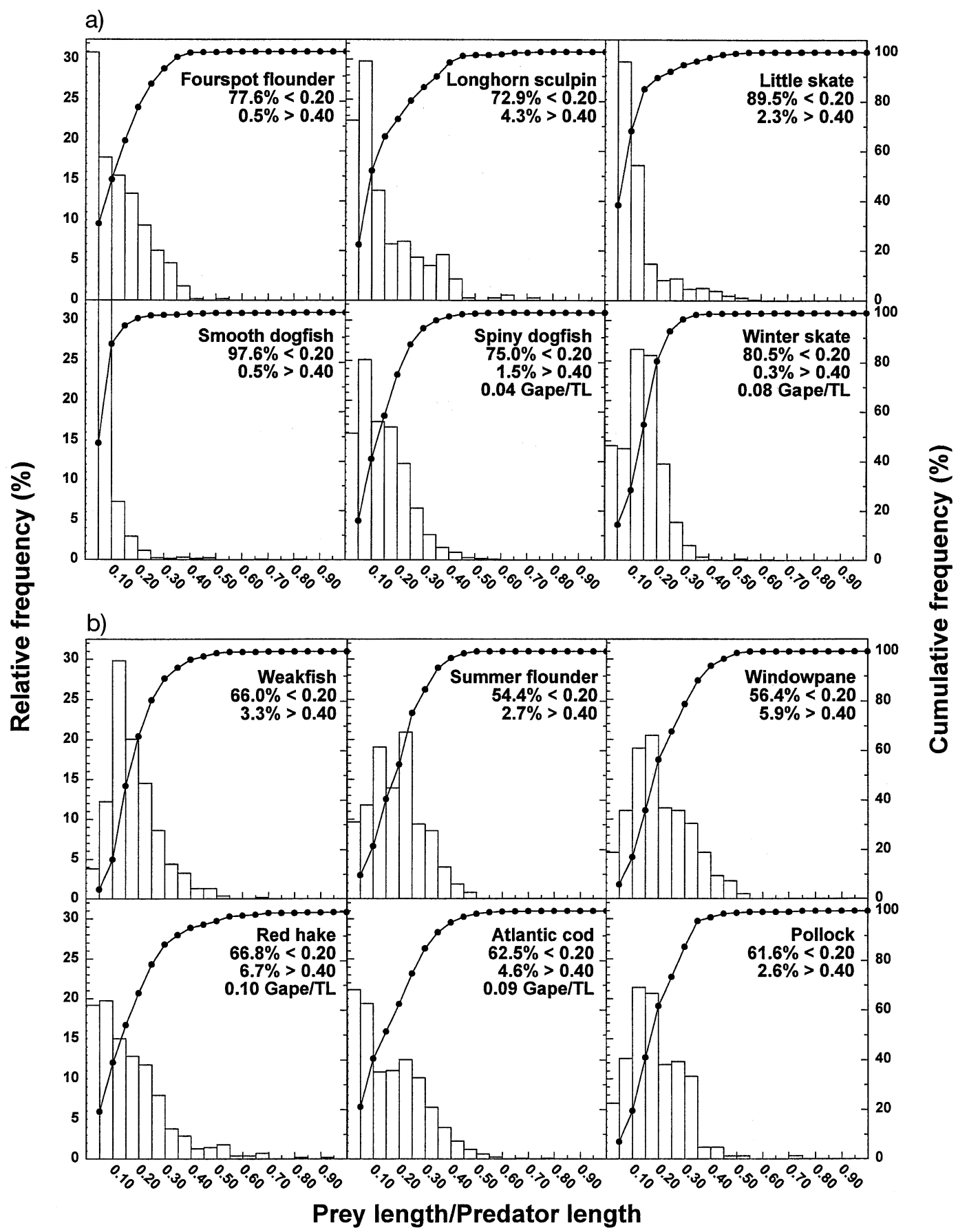

Fig. 4. Relative frequency distributions of prey size/predator size ratios consumed by marine fish predators. Cumulative frequencies are indicated by continuous lines with filled circles at $5 \%$ intervals of prey size/predator size ratios. (a) Predators that consume highest percentages of small prey relative to their body size $(\sim 75 \%$ or more of prey $<0.20$ prey size/predator size; $\sim 2 \%$ or less of prey $>0.40$ prey size/predator size); (b) predators consuming mostly intermediate-sized prey $(\sim 50$ to $75 \%$ of prey $<0.20$ prey size/predator size; $\sim 2$ to $7 \%$ of prey $>0.40$ prey size/predator size); (c) predators that consume the highest percentages of large prey relative to their body size $(\sim 50 \%$ or less of prey $<0.20$ prey size/predator size; $\sim 8$ to $54 \%$ of prey $>0.40$ prey

size/predator size). For predators with gape information, average ratio of gape size to body size (Gape/TL) is indicated

a wide variety of fish taxa (Folkvord \& Hunter 1986, Miller et al. 1988, Rice et al. 1993, Juanes \& Conover 1994, Ellis \& Gibson 1997, Scharf et al. 1998a). Much less is known about the size-dependence of encounter rates. Based on increases in predator reactive distances and prey swimming speeds with increasing 


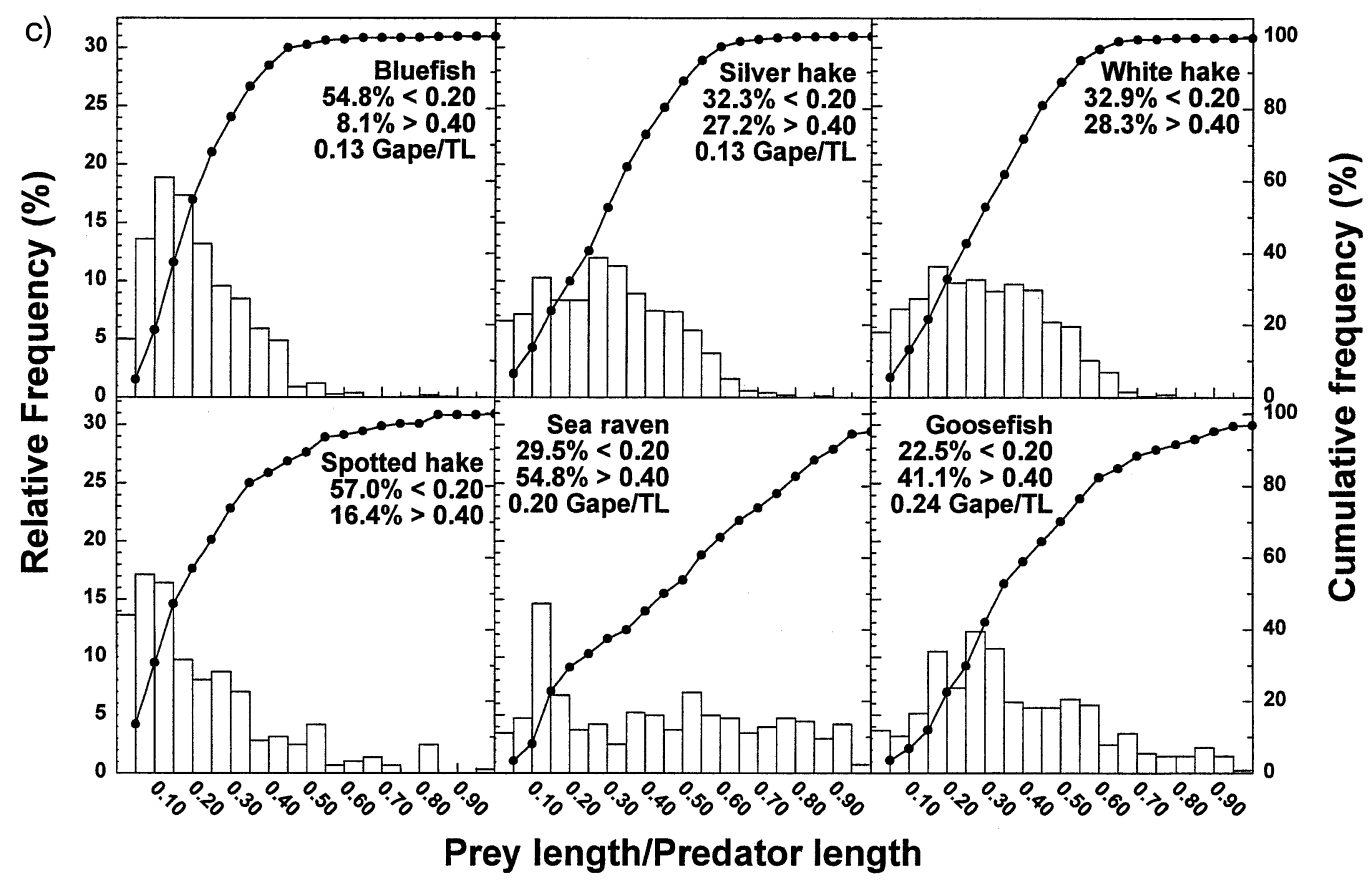

Fig. 4 (continued)

prey size, the probability of encounter is generally thought to increase with prey size, especially at smaller body sizes (Gerritsen \& Strickler 1977). The combination of increasing encounter probability and decreasing susceptibility to capture with individual body size produces a dome-shaped vulnerability curve for individual prey, with intermediate prey sizes being most vulnerable to predation. However, although the probability of an individual prey being encountered by a predator may increase with increasing body size, theory predicts that the total biomass of particles in marine ecosystems declines with increasing particle size (Sheldon et al. 1972, Kerr 1974, Platt \& Denman 1978). Therefore, the numbers of smaller prey available to predators may be substantially greater than the numbers of larger prey. High relative abundance of small prey may outweigh any size-based increases in individual encounter probabilities for larger prey, resulting in high predator encounter rates with small prey relative to large prey. The combination of high encounter rates, due to greater relative abundance, and high capture probability, means that small prey should always remain highly vulnerable to predation relative to larger prey. Considering that handling times increase rapidly with prey size, the retention of small prey in the diets of larger predators may reflect profitable foraging decisions by predators when search, capture, and handling costs are each considered.

Although predator size-prey size distributions for each predator species maintained the same general shape, considerable variability existed among predators in the sizes of prey consumed and ontogenetic relationships. In our study, increases in mean prey size were strongly correlated with increases in maximum prey size and were not statistically related to changes in minimum prey size. This is likely to be a common theme in patterns of prey size use because ontogenetic changes in maximum prey size will determine the overall shape of the distribution while minimum prey size remains relatively constant.

\section{Influence of predator morphology and behavior}

Observed differences among predators in patterns of prey size use can be attributed to variability in several morphological and behavioral characteristics. Difference in mouth morphology alone has been implicated as a major determinant of variation in prey types and sizes consumed by predatory fishes (Keast \& Webb 1966, Shirota 1970, Hunter 1981, Persson et al. 1996, Labropoulou \& Eleftheriou 1997, Piet et al. 1998). Gape size varied nearly 4 -fold among the predators examined in this study, with differences in gape size corresponding well with differences in the distribution of relative prey sizes eaten by each predator. For example, gape size to predator size ratios ranged from 0.04 to 0.24 and coincided directly with the percentages of large prey included in the diet (prey $>40 \%$ predator body size), which ranged from $1-2 \%$ for small-gaped 

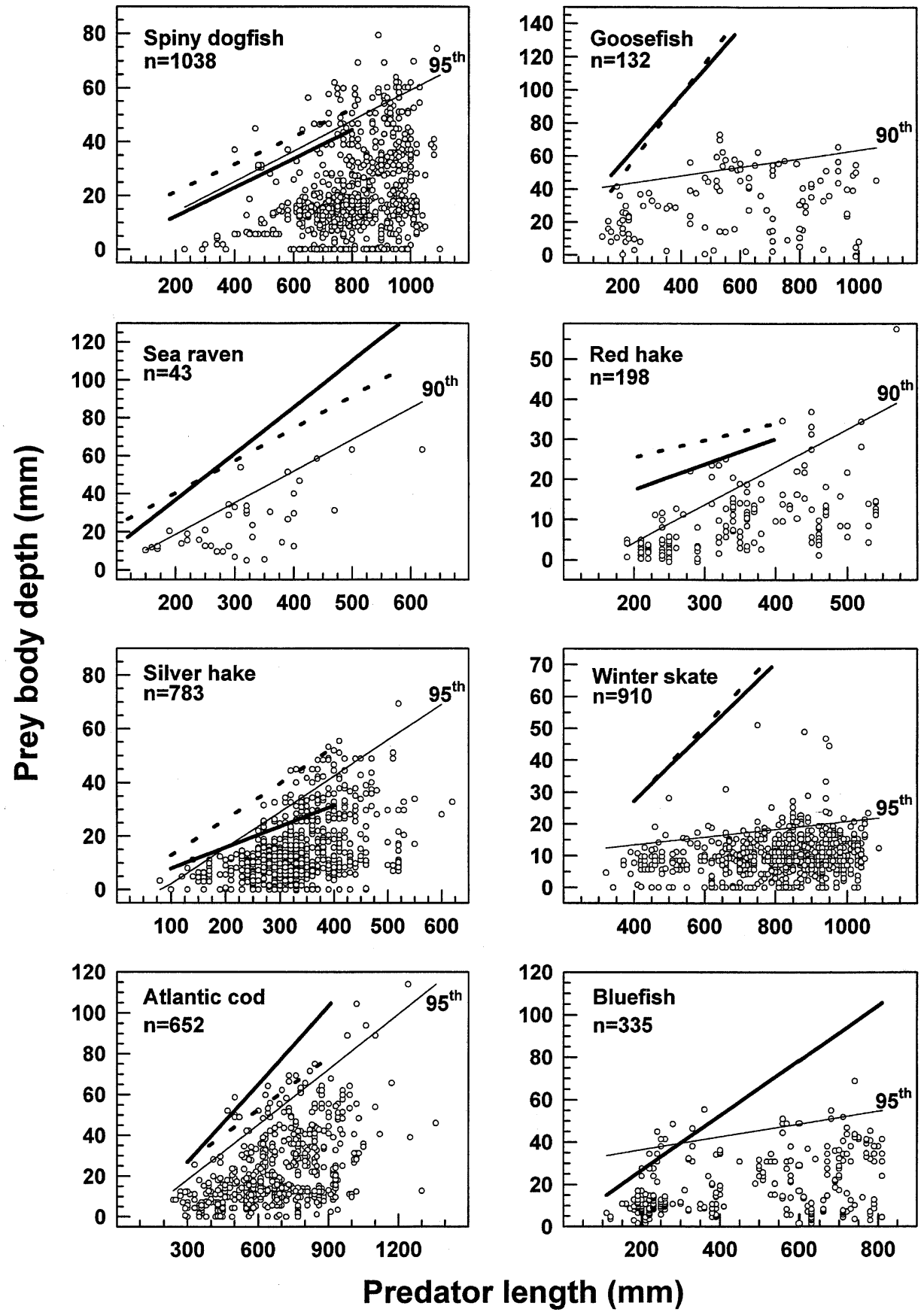

Fig. 5. Predator length - prey body depth scatter diagrams for 8 piscivorous fish predators. Each symbol (o) represents a single prey consumed by a predator. For each scatter diagram, thick continuous lines represent gape width vs predator size regressions and thick dashed lines represent gape height vs predator size regressions. Regression equations are presented in Table 3. Maximum prey body depth vs predator size regressions are also illustrated (thin continuous lines) with corresponding quantiles indicated. Only gape width information was available for bluefish

predators to $40-50 \%$ for large-gaped predators. Extremely large gape sizes allow predators such as sea raven and goosefish to exploit prey up to $80-90 \%$ of their own body size - resources normally utilized by predators twice their size. Predators that increase gape size rapidly also tend to feed primarily on fish prey relative to invertebrates. For example, sea raven and goosefish each have diets concentrated on fishes, including several larger species of clupeids and gadids. In contrast, smaller-gaped predators such as 
Table 3. Linear regression equations relating gape width, gape height, and maximum prey body depth consumed to total body length for 8 predator species. Only gape width was measured for bluefish. GW = gape width; GH = gape height; PYBD = prey body depth; $\mathrm{PD}=$ predator total length. All measurements and size range are in mm total length. $\mathrm{r}^{2}$ values, size range, and $\mathrm{n}$ refer to gape equations only; regression $\mathrm{p}$-values $=<0.05$ for all gape equations. $\mathrm{n}$ for body-depth equations are indicated in Fig. 5 . Probability values presented are for post-hoc slope comparisons between each gape equation and equation for maximum prey body depth eaten

\begin{tabular}{|c|c|c|c|c|c|c|}
\hline Predator species & Gape size & Gape at $400 \mathrm{~mm}$ & $\mathrm{r}^{2}$ & Size range & $\mathrm{n}$ & $\mathrm{p}$-value \\
\hline Winter skate & $\begin{array}{l}G W=0.108 P D-15.941 \\
G H=0.117 P D-19.699 \\
P Y B D=0.012 P D+8.446\end{array}$ & $\begin{array}{l}27 \\
27\end{array}$ & $\begin{array}{l}0.90 \\
0.87\end{array}$ & $\begin{array}{l}400-790 \\
400-790\end{array}$ & $\begin{array}{l}42 \\
42\end{array}$ & $\begin{array}{l}<0.001 \\
<0.001\end{array}$ \\
\hline Spiny dogfish & $\begin{array}{l}\mathrm{GW}=0.066 \mathrm{PD}-1.948 \\
\mathrm{GH}=0.051 \mathrm{PD}+11.230 \\
\mathrm{PYBD}=0.056 \mathrm{PD}+2.668\end{array}$ & $\begin{array}{l}24 \\
32\end{array}$ & $\begin{array}{l}0.69 \\
0.54\end{array}$ & $\begin{array}{l}180-840 \\
180-840\end{array}$ & $\begin{array}{l}101 \\
100\end{array}$ & $\begin{array}{l}>0.25 \\
>0.50\end{array}$ \\
\hline Red hake & $\begin{array}{l}\mathrm{GW}=0.064 \mathrm{PD}+4.609 \\
\mathrm{GH}=0.043 \mathrm{PD}+16.905 \\
\mathrm{PYBD}=0.094 \mathrm{PD}-14.541\end{array}$ & $\begin{array}{l}30 \\
34\end{array}$ & $\begin{array}{l}0.48 \\
0.41\end{array}$ & $\begin{array}{l}205-398 \\
205-398\end{array}$ & $\begin{array}{l}11 \\
11\end{array}$ & $\begin{array}{l}>0.75 \\
<0.05\end{array}$ \\
\hline Atlantic cod & $\begin{array}{l}\mathrm{GW}=0.128 \mathrm{PD}-11.689 \\
\mathrm{GH}=0.085 \mathrm{PD}+1.584 \\
\mathrm{PYBD}=0.090 \mathrm{PD}-8.911\end{array}$ & $\begin{array}{l}40 \\
36\end{array}$ & $\begin{array}{l}0.91 \\
0.87\end{array}$ & $\begin{array}{l}300-910 \\
300-910\end{array}$ & $\begin{array}{l}18 \\
18\end{array}$ & $\begin{array}{l}<0.05 \\
>0.75\end{array}$ \\
\hline Silver hake & $\begin{array}{l}\mathrm{GW}=0.076 \mathrm{PD}+1.011 \\
\mathrm{GH}=0.123 \mathrm{PD}+2.147 \\
\mathrm{PYBD}=0.134 \mathrm{PD}-11.154\end{array}$ & $\begin{array}{l}31 \\
51\end{array}$ & $\begin{array}{l}0.90 \\
0.81\end{array}$ & $\begin{array}{l}100-400 \\
100-400\end{array}$ & $\begin{array}{l}83 \\
83\end{array}$ & $\begin{array}{l}<0.001 \\
>0.25\end{array}$ \\
\hline Sea raven & $\begin{array}{l}\mathrm{GW}=0.244 \mathrm{PD}-12.095 \\
\mathrm{GH}=0.170 \mathrm{PD}+6.217 \\
\mathrm{PYBD}=0.166 \mathrm{PD}-14.441\end{array}$ & $\begin{array}{l}86 \\
74\end{array}$ & $\begin{array}{l}0.95 \\
0.60\end{array}$ & $\begin{array}{l}120-580 \\
120-580\end{array}$ & $\begin{array}{l}43 \\
42\end{array}$ & $\begin{array}{l}<0.001 \\
>0.75\end{array}$ \\
\hline Goosefish & $\begin{array}{l}\mathrm{GW}=0.202 \mathrm{PD}+15.881 \\
\mathrm{GH}=0.242 \mathrm{PD}+0.008 \\
\mathrm{PYBD}=0.026 \mathrm{PD}+37.596\end{array}$ & $\begin{array}{l}97 \\
97\end{array}$ & $\begin{array}{l}0.81 \\
0.93\end{array}$ & $\begin{array}{l}160-580 \\
160-580\end{array}$ & $\begin{array}{l}9 \\
9\end{array}$ & $\begin{array}{l}<0.001 \\
<0.001\end{array}$ \\
\hline Bluefish & $\begin{array}{l}\mathrm{GW}=0.129 \mathrm{PD}+0.840 \\
\mathrm{PYBD}=0.030 \mathrm{PD}+30.284\end{array}$ & 53 & 0.96 & $90-260$ & 21 & $<0.001$ \\
\hline
\end{tabular}

Table 4. Change in ratio-based trophic-niche breadth with increasing predator size for marine fishes on the US northeast continental shelf. Upper- and lower-bound slopes are quantile regressions estimating 90th (upper) and 10th (lower) quantiles of prey/predator size ratio vs predator size plots. Decreases or increases in trophic-niche width are based on statistically significant differences between upper- and lower-bound slope

\begin{tabular}{|c|c|c|c|}
\hline \multirow[t]{2}{*}{ Predator species } & \multicolumn{2}{|c|}{ Prey size/predator size ratio vs predator size } & \multirow{2}{*}{$\begin{array}{l}\text { Change in trophic- } \\
\text { niche breadth }\end{array}$} \\
\hline & Upper bound slope $( \pm \mathrm{SE})$ & Lower bound slope $( \pm \mathrm{SE})$ & \\
\hline Spotted hake & $-0.000120( \pm 0.000871)$ & $-0.000072( \pm 0.000077)$ & None \\
\hline Fourspot flounder & $0.000563( \pm 0.000314)$ & $0.000012( \pm 0.000038)$ & None \\
\hline Windowpane & $0.000545( \pm 0.000389)$ & $0.000468( \pm 0.000158)$ & None \\
\hline Longhorn sculpin & $-0.000680( \pm 0.000293)$ & $-0.000120( \pm 0.000053)$ & None \\
\hline Sea raven & $0.000132( \pm 0.000282)$ & $-0.000167( \pm 0.000059)$ & None \\
\hline Silver hake & $0.000254( \pm 0.000084)$ & $0.000280( \pm 0.000037)$ & None \\
\hline Red hake & $0.000675( \pm 0.000217)$ & $-0.000059( \pm 0.000006)$ & Increase \\
\hline Weakfish & $-0.000422( \pm 0.000110)$ & $-0.000124( \pm 0.000039)$ & Decrease \\
\hline Summer flounder & $0.000013( \pm 0.000128)$ & $0.000137( \pm 0.000039)$ & None \\
\hline Little skate & $-0.000022( \pm 0.000226)$ & $0.000017( \pm 0.000011)$ & None \\
\hline Bluefish & $-0.000133( \pm 0.000061)$ & $-0.000194( \pm 0.000014)$ & None \\
\hline White hake & $-0.000228( \pm 0.000040)$ & $0.000107( \pm 0.000035)$ & Decrease \\
\hline Goosefish & $-0.000770( \pm 0.000097)$ & $-0.000269( \pm 0.000042)$ & Decrease \\
\hline Atlantic cod & $-0.000074( \pm 0.000027)$ & $0.000042( \pm 0.000005)$ & Decrease \\
\hline Pollock & $-0.000087( \pm 0.000046)$ & $-0.000106( \pm 0.000015)$ & None \\
\hline Winter skate & $-0.000189( \pm 0.000016)$ & $0.000088( \pm 0.000012)$ & Decrease \\
\hline Spiny dogfish & $-0.000064( \pm 0.000027)$ & $0.000009( \pm 0.000006)$ & Decrease \\
\hline Smooth dogfish & $-0.000019( \pm 0.000031)$ & $-0.000004( \pm 0.000003)$ & None \\
\hline
\end{tabular}


spiny dogfish and Atlantic cod consume considerably more invertebrates, although larger prey eaten are mainly fishes (Fig. 2c). For both marine and freshwater fishes, previous studies have concluded that large gape relative to body size leads to an earlier shift to a piscivorous diet and that the timing of ontogenetic diet
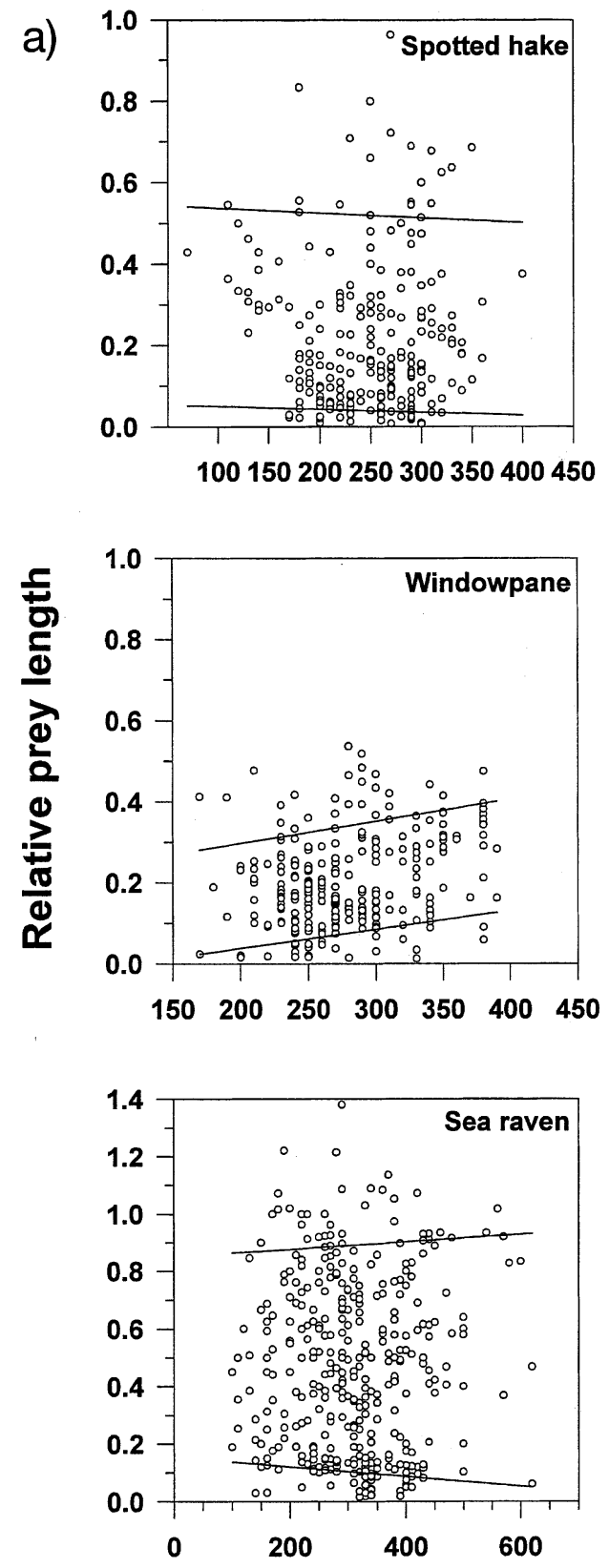

shifts have important effects on growth during the first year of life (Buijse \& Houthuijzen 1992, Juanes \& Conover 1995, Buckel et al. 1998, Mittelbach \& Persson 1998). Differences in gape allometries in later life stages, as observed for the predators in this study, can also impact diet composition and may have conse-
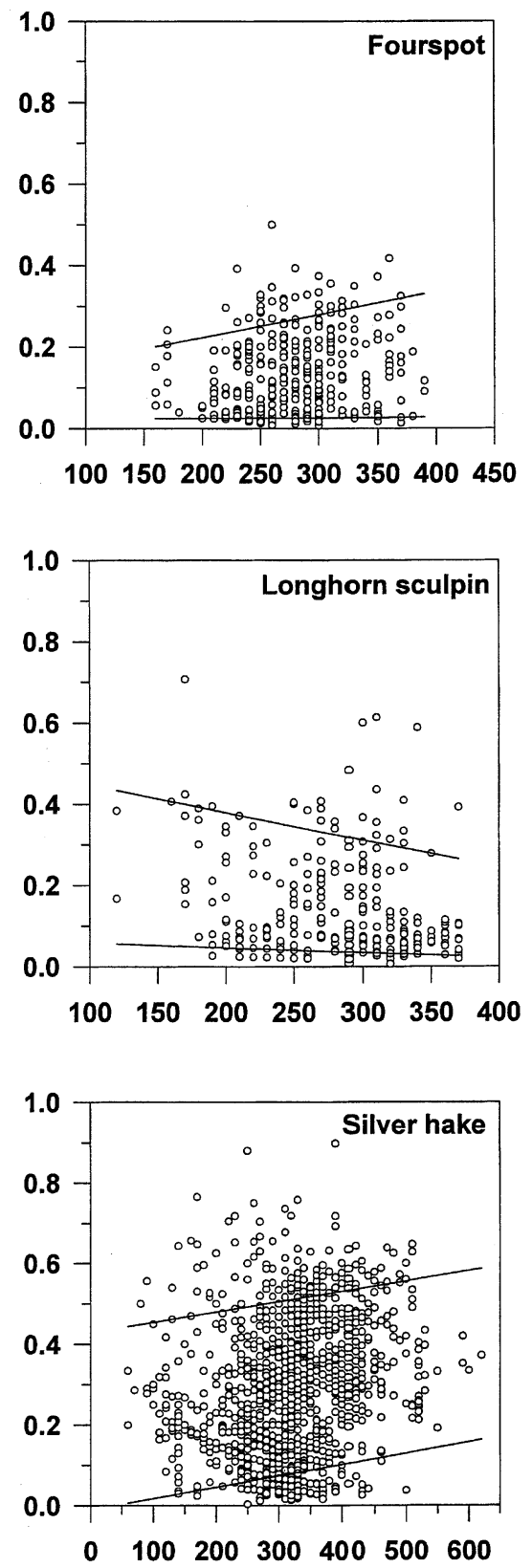

\section{Predator length $(\mathbf{m m})$}

Fig. 6. Scatter diagrams illustrating relative prey size (prey size/predator size ratio) as a function of predator size. Each symbol (o) represents relative size of a single prey consumed by a predator. Regression lines illustrate ontogenetic changes in the range of relative prey sizes consumed with increasing predator size; regression slopes for upper (90th quantile) and lower (10th quantile) bounds are presented in Table 4. Predators are shown in ascending order of mean size from upper left to lower right and from 
quences for growth and survival when resources are limited.

Gape size is not the only factor limiting maximum prey size consumed by fish predators. For example, Gaughan \& Potter (1997) compared the diets and mouth sizes of 5 estuarine species of larval fishes and concluded that mouth width had only a small influence on prey sizes eaten and that disparate feeding patterns among larvae were likely to be due to behavioral dif-
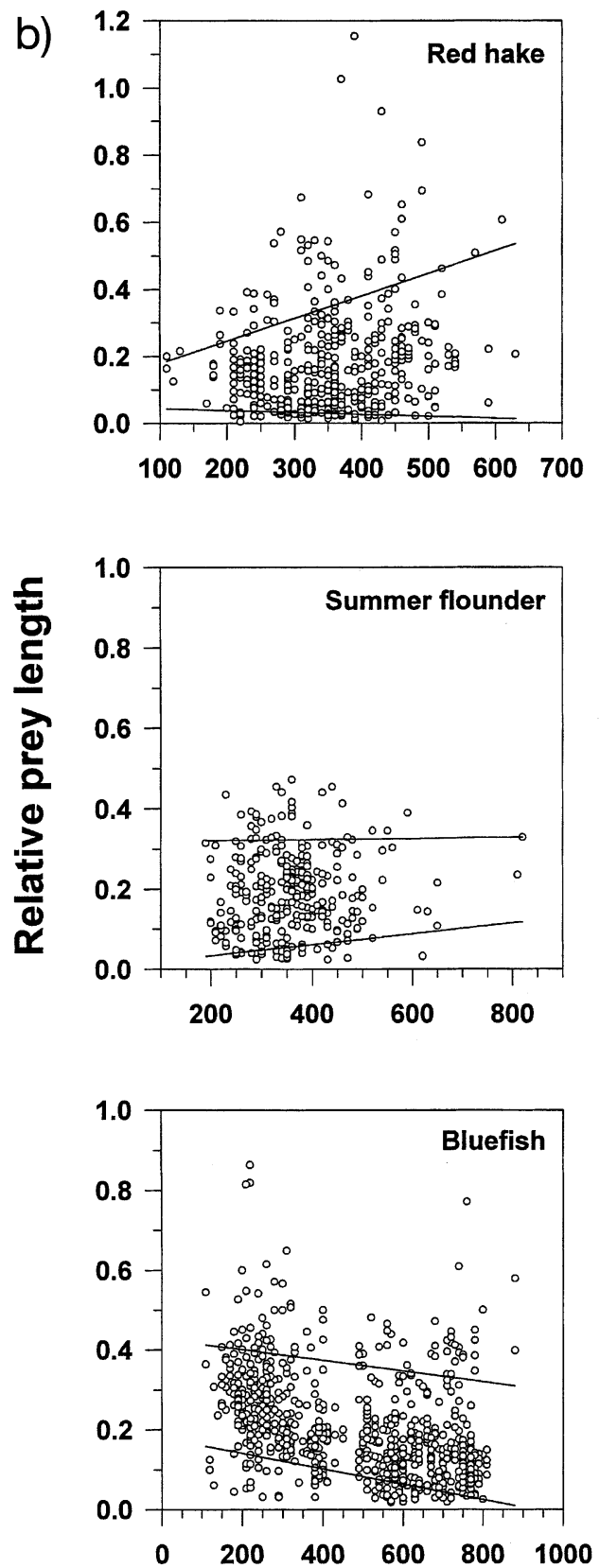

ferences. Other studies have also observed maximum prey sizes for fish predators well below morphological limits set by gape size, and have suggested that sizedependent prey-evasive behaviors and differences in prey availability may also limit the consumption of large prey (Hambright 1991, Keeley \& Grant 1997, Brooking et al. 1998). In our study, maximum prey sizes for goosefish, winter skate, and bluefish were also below those predicted by gape size. Our findings
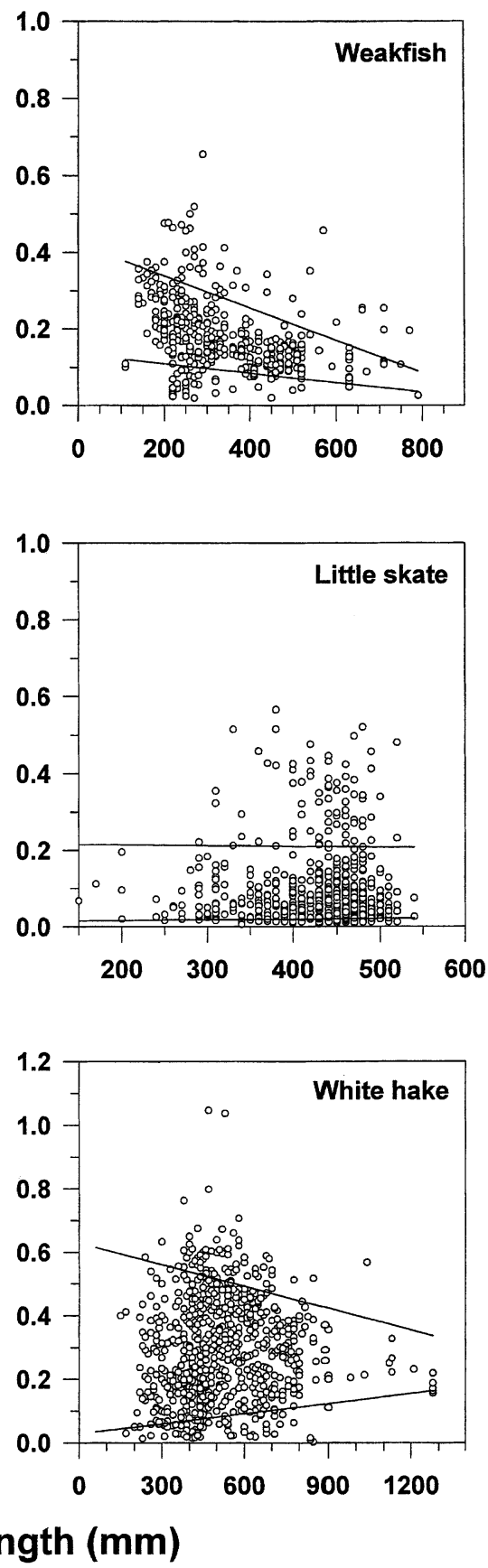

Fig. 6 (continued) 
for these 3 predators provide further evidence for the potential importance of factors other than predator gape size, such as behavior, prey availability, and predator capture efficiency, in limiting maximum prey size.

Size-based feeding strategies may also be related to predator foraging tactics, habitat overlap with prey, and morphological specializations that are particularly suited to specific habitats and/or prey types. Most predators utilize 1 of 2 basic encounter tactics, either lying in wait to ambush prey or cruising continually to locate prey (Greene 1986). Because of the dependence on prey movement to produce encounters, ambush predators are thought to encounter large, fast-moving prey more frequently than small, slow-moving prey (Greene 1983, 1985). The predators included in this study that exclusively employ ambush tactics, goosefish and sea raven, consumed the largest prey relative to their own size compared with other predators, which is consistent with theoretical predictions. Several pre-
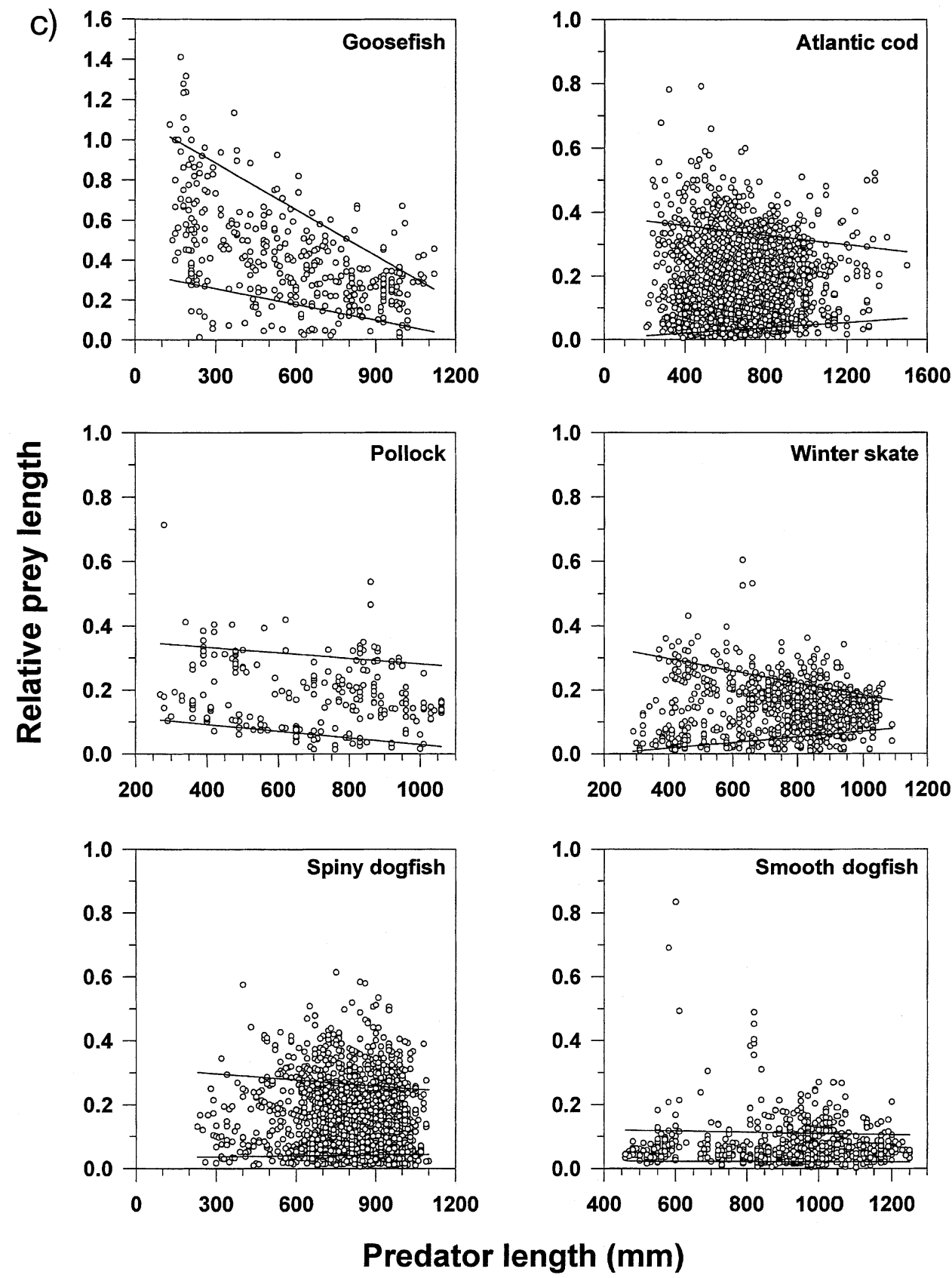

Fig. 6 (continued) 


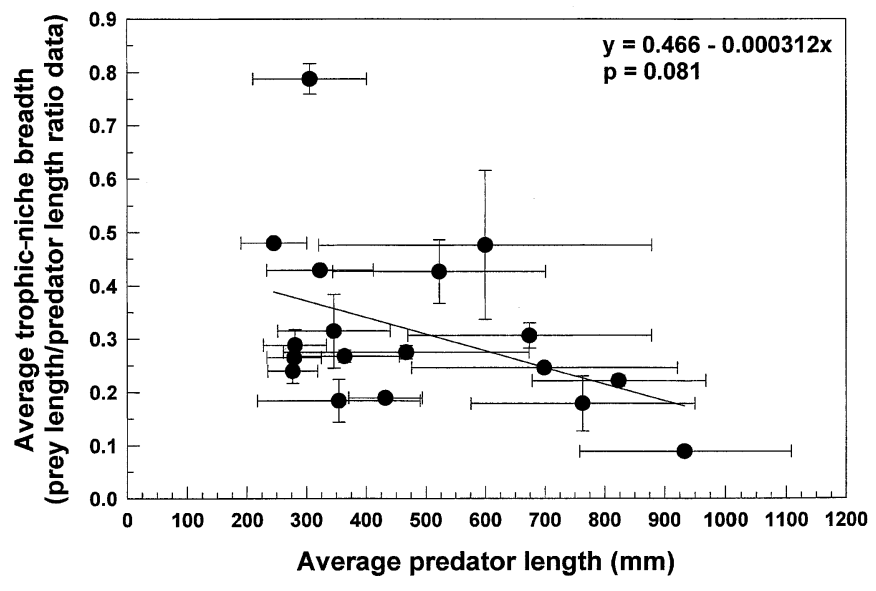

Fig. 7. Average trophic-niche breadth plotted against average predator size for trophic niche breadths calculated using prey size/predator size ratios. Error bars $= \pm 1 \mathrm{SE}$

dators in this study are bottom-oriented, and diets of these species may be biased towards the types and sizes of prey occupying benthic habitats. For example, the diets of several flatfishes, demersal groundfish, and elasmobranchs consist of an abundance of benthic prey including invertebrate crustaceans as well as fish species such as sand lance. Moreover, several elasmobranch predators included in this study have ventrally located mouths, with the feeding apparatus of skates being specialized to crush hard-bodied prey. Together with a benthic lifestyle, mouth morphology and location probably have significant effects on patterns of prey type and size use for these predators. In contrast, predators with a more pelagic lifestyle, such as bluefish, feed mainly on schooling fishes and squid that are located up in the water column. In addition to morphology, general feeding tactics, and habitat associa- tions, seasonal movements of predators related to both latitude and depth result in varying patterns of spatial and temporal overlap with prey, which will ultimately contribute to patterns of prey size use.

\section{Trophic-niche breadth variation as a function of relative prey size}

Ontogenetic changes in ratio-based trophic-niche breadths were not evident for many of the predator taxa we examined, which is consistent with several previous studies (Pearre 1986, Munk 1992, 1997). For most of the smallest predators, we observed no significant change in trophic-niche breadths. For several of the largest predators, however, there was a general trend to indicate a decrease in the breadth of relative prey sizes eaten with ontogeny. Pearre (1986) conducted the most inclusive study of trophic-niche breadths in fishes, examining 45 data sets on 43 species. Although broad taxonomically, the species included were mainly larvae and small juveniles, with only 3 species larger than $200 \mathrm{~mm}$ average size and an additional 6 species larger than $100 \mathrm{~mm}$ average size (Pearre 1986). Other recent studies of trophic-niche breadth have similarly been focused on larval and juvenile fishes (Munk 1992, 1997, Pepin \& Penney 1997).

The trend for decreasing trophic-niche breadths with ontogeny observed in our study was only present in large predators with average sizes $>500 \mathrm{~mm}$. This finding is likely to be a common one when large predators are examined for ontogenetic changes in the relative sizes of prey consumed. The distribution of body sizes of potential prey probably remains fairly constant when examined collectively across a time period of

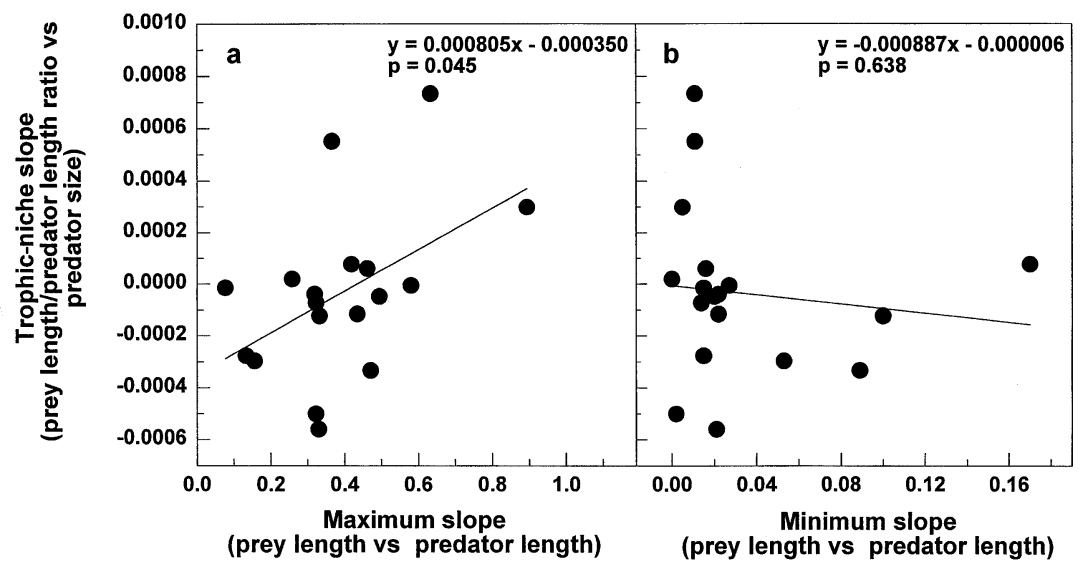

Fig. 8. Trophic-niche slope (generated from ratio-based trophic-niche breadth vs predator size regressions) plotted against (a) maximum and (b) minimum prey size slopes (generated from prey size vs predator size regressions). Fitted regression equations and significance levels are indicated 
several years, such as the lifespan of a large predator. If this assumption is generally true, then the range of relative prey sizes available to a growing predator will necessarily decrease with time. That is, the frequency distribution of relative prey sizes will become skewed to the right as the frequency of larger prey size/predator size ratios declines with increasing predator body size. In contrast to the results of previous research, Pepin \& Penney (1997) observed increases in trophicniche breadth for 6 of 11 species of larval fishes, which led them to conclude that general size-based trends may not exist across taxa, but rather that patterns of prey size use are species-specific. Our results highlight the need for future research to examine ratio-based trophic-niche breadth across large size ranges and ontogenetic stages to determine if generalizations can be made across taxa.

The conclusions of previous ratio-based analyses that prey size is a constant proportion of predator size through ontogeny has recently been questioned (Houde 1997). For fishes, the range of absolute prey sizes clearly increases as predators grow, regardless of life stage. However, changes in relative prey sizes consumed are difficult to detect. When comparing patterns based on absolute prey sizes versus relative prey sizes, the apparent differences in trophic-niche breadths are not contradictory, but rather represent different perspectives of the predator-prey interaction. The expansion of absolute prey size range by most predators is probably representative of increases in behavioral and morphological capability to capture and swallow large prey combined with high encounter rates and susceptiblity to capture of small prey. Moreover, knowledge of the range of absolute prey sizes vulnerable to specific predators is critical in order to quantify the impact of predators on prey populations and community structure. On the other hand, subtle changes in the range of relative prey sizes eaten may represent slight ontogenetic changes in predator foraging abilities and/or ontogenetic shifts to prey types with different escape proficiencies. Further, modest changes in ratio-based trophic-niche breadths may be specific to particular life stages and may only be detectable when analyzed on an appropriate scale. For example, Houde (1997) suggested that the foraging strategy of growing larvae is one that ensures expansion of prey sizes in the diet in order to increase encounter rates between larval fish and potential prey.

\section{CONCLUSIONS}

Asymmetric predator size - prey size distributions are frequently observed across several animal taxa. The consistent inclusion of small-bodied prey in the diets of large predators probably represents profitable foraging behaviors when size-dependent probabilities of encounter and capture are combined with handling costs of prey. The prominent role of size-based rates of encounter and capture in determining the types and sizes of prey consumed demonstrates the importance of species specific morphological and behavioral characteristics of both predator and prey. Variation among predators in size-based feeding strategies can be related to differences in predator gape allometry, foraging tactics, morphological specializations, and migratory behavior as well as individual prey behavior and morphology. How these species specific traits scale ontogenetically between predator and prey will be a major determinant of changes in resource use (prey size and type) by growing predators. Although the range of absolute prey sizes eaten typically increases with predator size, ontogenetic changes in relative prey sizes eaten are often statistically undetectable, suggesting that changes in predator foraging abilities with size may be subtle and that their detection requires analysis on an appropriate scale.

Acknowledgements. We gratefully acknowledge the staff of the Northeast Fisheries Science Center for collecting, editing, and organizing the food habits database and for allowing us to present it here. This research was supported by the Cooperative Marine Education and Research program of the National Oceanic and Atmospheric Administration and the Hudson River Foundation for Science and Environmental Research. We also thank J. Boreman, J. Link, M. Sutherland, A. Stoner, and several anonymous referees for critical reviews and comments that improved the manuscript. The US Government is authorized to produce and distribute reprints for governmental purposes notwithstanding any copyright notation that may appear hereon. The views expressed herein are those of the authors and do not necessarily reflect the view of NOAA or any of its sub-agencies.

\section{LITERATURE CITED}

Azarovitz TR (1981) A brief historical review of the Woods Hole laboratory trawl survey time series. Can Spec Publ Fish Aquat Sci 58:62-67

Beamish FWH (1978) Swimming capacity. In: Hoar WS, Randall DJ (eds) Fish physiology. Academic Press, New York, p 101-187

Bigelow HB, Schroeder WC (1953) Fishes of the Gulf of Maine. Fish Bull Fish Wildl Serv US 53:1-577

Blaxter JHS (1986) Development of sense organs and behavior of teleost larvae with special reference to feeding and predator avoidance. Trans Am Fish Soc 115:98-114

Blaxter JHS, Fuiman LA (1990) The role of the sensory systems of herring larvae in evading predatory fishes. J Mar Biol Assoc UK 70:413-427

Breck JE (1993) Foraging theory and piscivorous fish: are forage fish just big zooplankton? Trans Am Fish Soc 122: 902-911

Brooking TE, Rudstam LG, Olson MH, VanDeValk AJ (1998) Size-dependent alewife predation on larval walleyes in laboratory experiments. N Am J Fish Manage 18:960-965 
Brooks JL, Dodson SI (1965) Predation, body size, and composition of plankton. Science 150:28-35

Buckel JA, Letcher BH, Conover DO (1998) Effects of a delayed onset of piscivory on the size of age-0 bluefish. Trans Am Fish Soc 127:576-587

Buijse AD, Houthuijzen RP (1992) Piscivory, growth, and sizeselective mortality of age 0 pikeperch (Stizostedion lucioperca). Can J Fish Aquat Sci 49:894-902

Cade BS, Terrell JW, Schroeder RL (1999) Estimating effects of limiting factors with regression quantiles. Ecology 80: 311-323

Charnov EL (1976) Optimal foraging: the marginal value theorem. Theor Popul Biol 9:129-136

Christensen B (1996) Predator foraging capabilities and prey antipredator behaviours: pre-versus postcapture constraints on size-dependent predator-prey interactions. Oikos 76:368-380

Edwards RL, Bowman RE (1979) Food consumed by continental shelf fishes. In: Clepper H (ed) Predator-prey systems in fisheries management. Sports Fishing Institute, Washington, DC, p 387-406

Eggers DM (1977) The nature of prey selection by planktivorous fish. Ecology 58:46-59

Ellis T, Gibson RN (1997) Predation of 0-group flatfishes by 0 -group cod: handling times and size-selection. Mar Ecol Prog Ser 149:83-90

Folkvord A, Hunter JR (1986) Size-specific vulnerability of northern anchovy, Engraulis mordax, larvae to predation by fishes. Fish Bull 84:859-869

Gaughan DJ, Potter IC (1997) Analysis of diet and feeding strategies within an assemblage of estuarine larval fish and an objective assessment of dietary niche overlap. Fish Bull 95:722-731

Gerritsen J, Strickler JR (1977) Encounter probabilities and community structure in zooplankton: a mathematical model. J Fish Res Board Can 34:73-82

Gillen AL, Stein RA, Carline RF (1981) Predation by pelletreared tiger muskellunge on minnows and bluegills in experimental systems. Trans Am Fish Soc 110:197-209

Greene CH (1983) Selective predation in freshwater zooplankton communities. Int Rev Hydrobiol 68:297-315

Greene CH (1985) Planktivore functional groups and patterns of prey selection in pelagic communities. J Plankton Res 7: $35-40$

Greene CH (1986) Patterns of prey selection: implications of predator foraging tactics. Am Nat 128:824-839

Hall DJ, Cooper WE, Werner EE (1970) An experimental approach to the production dynamics and structure of freshwater animal communities. Limnol Oceanogr 15: 829-928

Hambright KD (1991) Experimental analysis of prey selection by largemouth bass: role of predator mouth width and prey body depth. Trans Am Fish Soc 120:500-508

Harper DG, Blake RW (1988) Energetics of piscivorous predator-prey interactions. J Theor Biol 134:59-76

Hart PJB, Hamrin SF (1990) The role of behaviour and morphology in the selection of prey by pike. In: Hughes RN (ed) Behavioural mechanisms of food selection. SpringerVerlag, Berlin, p 235-253

Houde ED (1997) Patterns and consequences of selective processes in teleost early life histories. In: Chambers RC, Trippel EA (eds) Early life history and recruitment in fish populations. Chapman \& Hall, London, p 173-196

Hoyle JA, Keast A (1987) The effect of prey morphology and size on handling time in a piscivore, the largemouth bass (Micropterus salmoides). Can J Zool 65:1972-1977

Hunter JR (1981) Feeding ecology and predation of marine larvae. In: Lasker R (ed) Marine fish larvae: morphology, ecology and relation to fisheries. University of Washington Press, Seattle, p 34-77

Ivlev VS (1961) Experimental ecology of the feeding of fishes Yale University Press, New Haven

Juanes $F$ (1994) What determines prey size selectivity in piscivorous fishes? In: Stouder DJ, Fresh KL, Feller RJ (eds) Theory and application in fish feeding ecology. Carolina University Press, Columbia, p 79-100

Juanes F, Conover DO (1994) Piscivory and prey size selection in young-of-the-year bluefish: predator preference or sizedependent capture success? Mar Ecol Prog Ser 114:59-69

Juanes F, Conover DO (1995) Size-structured piscivory: advection and the linkage between predator and prey recruitment in young-of-the-year bluefish. Mar Ecol Prog Ser 128:287-304

Keast A, Webb D (1966) Mouth and body form relative to feeding ecology in the fish fauna of a small lake, Lake Opinicon, Ontario. J Fish Res Board Can 23:1845-1874

Keeley ER, Grant JWA (1997) Allometry of diet selectivity in juvenile Atlantic salmon (Salmo salar). Can J Fish Aquat Sci 54:1894-1902

Kerr SR (1974) Theory of size distribution in ecological communities. J Fish Res Board Can 31:1859-1862

Kislalioglu M, Gibson RN (1976) Prey 'handling time' and its importance in food selection by the 15-spined stickleback, Spinachia spinachia (L.). J Exp Mar Biol Ecol 25:151-158

Labropoulou M, Eleftheriou A (1997) The foraging ecology of two pairs of congeneric demersal fish species: importance of morphological characteristics in prey selection. J Fish Biol 50:324-340

Langton RW, Bowman RE (1980) Food of fifteen Northwest Atlantic gadiform fishes. NOAA Natl Fish Serv Tech Rep US Dep Commerce SSRF-740:1-23

Langton RW, Bowman RE (1981) Food of eight Northwest Atlantic pleuronectiform fishes. NOAA Natl Fish Serv Tech Rep US Dep Commerce SSRF-749:1-16

Litvak MK, Leggett WC (1992) Age and size-selective predation on larval fishes: the bigger-is-better hypothesis revisited. Mar Ecol Prog Ser 81:13-24

Miller TJ, Crowder LB, Rice JA, Marschall EA (1988) Larval size and recruitment mechanisms in fishes: toward a conceptual framework. Can J Fish Aquat Sci 45:1657-1670

Mittelbach GG (1981) Foraging efficiency and body size: a study of optimal diet and habitat use by bluegills. Ecology 62:1370-1386

Mittelbach GG, Persson L (1998) The ontogeny of piscivory and its ecological consequences. Can J Fish Aquat Sci 55:1454-1465

Munk P (1992) Foraging behaviour and prey size spectra of larval herring Clupea harengus. Mar Ecol Prog Ser 80: 149-158

Munk P (1997) Prey size spectra and prey availability of larval and small juvenile cod. J Fish Biol 51(Suppl A):340-351

Nielsen LA (1980) Effect of walleye (Stizostedion vitreum vitreum) predation on juvenile mortality and recruitment of yellow perch (Perca flavescens) in Oneida Lake, New York. Can J Fish Aquat Sci 37:11-19

Pearre S Jr (1986) Ratio-based trophic niche breadths of fish, the Sheldon spectrum, and the size-efficiency hypothesis. Mar Ecol Prog Ser 27:299-314

Pepin P, Penney RW (1997) Patterns of prey size and taxonomic composition in larval fish: are there general sizedependent models? J Fish Biol 51(Suppl A):84-100

Persson L (1990) Predicting ontogenetic niche shifts in the field: what can be gained by foraging theory? In: Hughes RN (ed) Behavioural mechanisms of food selection. Springer-Verlag, Berlin, p 303-321 
Persson L, Andersson J, Wahlstrom E, Eklov P (1996) Sizespecific interactions in lake systems: predator gape limitation and prey growth rate and mortality. Ecology 77: 900-911

Piet GJ, Pfisterer AB, Rijnsdorp AD (1998) On factors structuring the flatfish assemblage in the southern North Sea. J Sea Res 40:143-152

Platt T, Denman K (1978) The structure of pelagic marine ecosystems. Rapp PV Réun Cons Int Explor Mer 173: $60-65$

Popova OA (1967) The 'predator-prey' relationship among fish. In: Gerking SD (ed) The biological basis of freshwater fish production. Blackwell Scientific Publications, Oxford, p 359-376

Popova OA (1978) The role of predaceous fish in ecosystems. In: Gerking SD (ed) Ecology of freshwater fish production. John Wiley \& Sons, New York, p 215-249

Rice JA, Crowder LB, Rose KA (1993) Interactions between size-structured predator and prey populations: experimental test and model comparison. Trans Am Fish Soc 122:481-491

Roughgarden J (1972) Evolution of niche width. Am Nat 106: 683-718

Roughgarden J (1974) Niche width: biogeographic patterns among Anolis lizard populations. Am Nat 108:429-442

Scharf FS, Buckel JA, Juanes F, Conover DO (1998a) Predation by juvenile piscivorous bluefish (Pomatomus saltatrix): the influence of prey to predator size ratio and prey type on predator capture success and prey profitability. Can J Fish Aquat Sci 55:1695-1703

Scharf FS, Juanes F, Sutherland M (1998b) Inferring ecological relationships from the edges of scatter diagrams: comparison of regression techniques. Ecology 79:448-460

Scharf FS, Yetter RM, Summers AP, Juanes F (1998c) Enhancing diet analyses of piscivorous fishes in the Northwest Atlantic through identification and reconstruction of original prey sizes from ingested remains. Fish Bull 96:575-588

Schoener TW (1971) Theory of feeding strategies. Annu Rev Ecol Syst 2:369-404

Schoener TW, Gorman GC (1968) Some niche differences in

Editorial responsibility: Howard Browman (Contributing

Editor), Storebø, Norway three Lesser Antillean lizards of the genus Anolis. Ecology 49:819-830

Sedberry, GR (1983) Food habits and trophic relationships of a community of fishes on the outer continental shelf. NOAA Natl Fish Serv Tech Rep US Dep Commerce SSRF773:1-56

Sheldon RW, Prakash A, Sutcliffe WH (1972) The size distribution of particles in the ocean. Limnol Oceanogr 17: $327-340$

Shirota A (1970) Studies on the mouth size of fish in the larval and fry stages. Bull Jpn Soc Sci Fish 36:353-368

Sih A, Moore RD (1990) Interacting effects of predator and prey behavior in determining diets. In: Hughes RN (ed) Behavioural mechanisms of food selection. SpringerVerlag, Berlin, p 771-796

Sokal RR, Rohlf FJ (1995) Biometry. The principles and practice of statistics in biological research. WH Freeman and Company, New York

StataCorp (1999) Stata statistical software: release 6.0. College Station, TX

Stein RA, Goodman CG, Marschall EA (1984) Using time and energetic measures of cost in estimating prey value for fish predators. Ecology 65:702-715

Stephens DW, Krebs JR (1986) Foraging theory. Princeton University Press, Princeton

Wanzenböck J (1995) Changing handling times during feeding and consequences for prey size selection of $0+$ zooplanktivorous fish. Oecologia 104:372-378

Webb PW (1976) The effect of size on the fast-start performance of rainbow trout, Salmo gardneri, and a consideration of piscivorous predator-prey interactions. J Exp Biol 65:157-177

Werner EE (1974) The fish size, prey size, handling time relation in several sunfishes and some implications. J Fish Res Board Can 31:1531-1536

Werner EE, Hall DJ (1974) Optimal foraging and the size selection of prey by the bluegill sunfish (Lepomis macrochirus). Ecology 55:1042-1052

Wilson DS (1975) The adequacy of body size as a niche difference. Am Nat 109:769-784

Submitted: January 3, 2000; Accepted: May 30, 2000

Proofs received from author(s): November 13, 2000 